\title{
ORIGINALISM, BALANCED LEGAL REALISM AND JUDICIAL SELECTION: A CASE STUDY
}

\author{
Stephen J. Ware*
}

The "balanced realist" view that judging inevitably involves lawmaking is widely accepted, even among originalists, such as Justice Scalia, Randy Barnett and Steven Calabresi. Yet many lawyers are still reluctant to acknowledge publicly the inevitability of judicial lawmaking. This reluctance is especially common in debates over the Missouri Plan, a method of judicial selection that divides the power to appoint judges between the governor and the bar.

The Missouri Plan is one of three widely-used methods of selecting state court judges. The other two are: (1) direct election of judges by the citizenry, and (2) appointment of judges by democratically elected officials, typically the governor and legislature, with little or no role for the bar. Each of these two methods of judicial selection respects a democratic society's basic equality among citizens-the principle of one-person, one-vote. In contrast, the Missouri Plan violates this principle by making a lawyer's vote worth more than another citizen's vote.

This Article provides a case study of the clash between the inevitability of judicial lawmaking and the reluctance of lawyers to acknowledge this inevitability while defending their disproportionate power under the Missouri Plan. The Article documents efforts by lawyers in one state, Kansas, to defend their version of the Missouri Plan by attempting to conceal from the public the fact that Kansas judges, like judges in the other 49 states, inevitably make law. The case study then shows examples of Kansas judges making law. The Article concludes that honesty requires lawyers participating in the debate over judicial selection in the United States to forthrightly acknowledge that judges make law. Lawyers who seek to defend the power advantage the Missouri Plan gives them over other citizens can honestly acknowledge that this is a power advantage in the selection of lawmakers and then explain why they believe a departure from the principle of one-person, one-vote is justified in

* Professor of Law, University of Kansas School of Law. Thanks to Randy Barnett, Charles Gardner Geyh, Brian Tamanaha, Todd Pettys, Tom Stacy, Rick Levy, Lou Mulligan, and Stephen Markman for helpful comments and to Joel Griffiths, Alex Aguilera, Laurel Kupka, and Darin VanThornout for excellent research assistance. 
the selection of these particular lawmakers.

\section{INTRODUCTION}

Judges make law. It is not the only thing judges do. They also run courtrooms, hire clerks and attend meetings. But amidst these other sorts of activities, judges also make law. We have known this at least since the legal realists of the early 20th Century. With the growth, and then dominance, of legal realism over the course of the last century, it is now a truism that judges make law. ${ }^{1}$

Yet many judges and lawyers are still reluctant to acknowledge publicly the inevitability of judicial lawmaking. In fact, judges and lawyers sometimes publish statements that tend to conceal from the public the fact that judges make law-for example, statements describing the judicial role in a way that omits the lawmaking part of this role. These omissions are especially common in debates over the Missouri Plan, a method of judicial selection that divides the power to appoint judges between the governor and the bar. ${ }^{2}$

The Missouri Plan is one of three widely-used methods of selecting state court judges. ${ }^{3}$ The other two are: (1) direct election of judges by the citizenry, and (2) appointment of judges by democratically elected officials, typically the governor and/or legislature, with little or no role for the bar. Each of these two methods of judicial selection respects a democratic society's basic equality among citizens - the principle of one-person, one-vote. Judicial elections directly vindicate this principle and appointment of judges indirectly vindicates it if the appointment is by officials who themselves were elected under the principle of one-person, one-vote. ${ }^{4}$ In contrast, the Missouri Plan violates this

1. See infra notes $40-41$ and accompanying text.

2. Several variants of the Missouri Plan are in use but they have the following in common: When a vacancy on the bench occurs, a nominating commission assesses applicants and narrows the pool of applicants from which the governor may select, typically to three; the governor then must pick one of those three and that person is thereby appointed to the court without any further process, such as a confirmation vote in the legislature; crucially, some members of the commission are selected by the bar. See infra notes 68-71 and accompanying text (describing the process in greater detail). Unfortunately, prominent bar groups use the term "merit selection" rather than "Missouri Plan" to describe all judicial appointment systems with a nominating commission of any sort, regardless of who selects the commission or whether the commission's power is checked by a confirmation vote in the legislature. Stephen J. Ware, The Missouri Plan in National Perspective, 74 Mo. L. REv. 751, 760-61 (2009). "This term, 'merit selection,' is 'propagandistic' and obscures important distinctions among appointive systems. Accordingly, I suggest that people reject the term 'merit selection' in favor of the more-neutral 'Missouri Plan' and that people reserve the term 'Missouri Plan' for [judicial selection systems] that lack confirmation by the senate or similar popularly elected body." Id. at 761-62 (internal citations omitted).

3. See id. at 752-64 (describing the various methods used).

4. See id. at 754-55 ("In those states in which the governor may appoint to the court whomever he or she wants, subject only to confirmation by a popularly elected body such as the state senate, judicial selection is laudably democratic because governors and state senators are elected under the principle of one-person-one-vote. In these elections, members of the bar get no 
principle by making a lawyer's vote worth more than another citizen's vote. ${ }^{5}$ The Missouri Plan's central problem is that it is undemocratic.

This problem's importance, however, is apparent only to those who realize that judges are lawmakers. We all realize that governors and legislators are lawmakers so each of the fifty United States selects governors and legislatures democratically, in direct elections. We also generally use a form of democracy - the indirect democracy of appointment by governors and legislatures - to select the leaders of the various government departments, boards and commissions that administer a modern state because we understand that these officials also make law. In contrast, we do not select our doctors, plumbers and hairdressers democratically because we understand that these jobs do not entail making law.

In general, lawmakers in our society are selected democratically and nonlawmakers are not selected democratically. However, judges selected by the Missouri Plan are incongruous; they are lawmakers but they are not selected democratically. They are not selected in accord with the basic democratic principle of one-person, one-vote.

Quite simply, the Missouri Plan is an aberrant violation of our society's practice of selecting lawmakers democratically. This undemocratic aberration empowers lawyers at the expense of non-lawyers so it is disappointing, but perhaps not surprising, that lawyers are prominent among those who defend the Missouri Plan. Unfortunately, their defense sometimes includes statements that may mislead the public into believing that judges do not make law. Rather than candidly educating the public about the judicial role, some lawyers arguing for a judicial selection system that especially empowers them make arguments based on a mythical view of judging that was refuted nearly a century ago by the legal realists.

The first section of this article briefly outlines the standard, "balanced realist" view that judging inevitably involves lawmaking. In doing so, it explains how widely accepted this view is, even among originalists, such as Justice Scalia, Randy Barnett and Steven Calabresi. Section II documents efforts by lawyers and judges in one state, Kansas, to defend their (especially

special powers.").

5. See supra note 2. To say that the Missouri Plan violates the principle of one-person-onevote is not to say that the Missouri Plan therefore violates the Equal Protection Clause of the U.S. Constitution. The Supreme Court's Equal Protection case law does not require all government officials to be selected in accord with one-person-one-vote, see, e.g., Nelson Lund, May Lawyers Be Given the Power to Elect Those Who Choose Our Judges? "Merit Selection" and Constitutional Law, 34 HARV. J.L. \& PUB. POL'Y 1043, 1050-60 (2011), and three federal circuit courts have held that various versions of the Missouri Plan fall within these exceptions. See Dool v. Burke, No. 10-3320, 2012 WL 4017118 (10th Cir. Sept. 13, 2012) (Kansas), Carlson v. Wiggins, 675 F.3d 1134, 1140-42 (8th Cir. 2012) (Iowa), Kirk v. Carpenti, 623 F.3d 889, 890 (9th Cir.2010) (Alaska). For a contrary view, see Dool v. Burke, No. 10-3320, 2012 WL 4017118 (10th Cir. Sept. 13, 2012) (McKay, J., dissenting); Lund, supra; Joshua Ney, Note, Does the Kansas Supreme Court Selection Process Violate the One Person, One Vote Doctrine?, 49 WASHBURN L.J. 143 (2009). 
undemocratic) version of the Missouri Plan by attempting to conceal from the public the fact that Kansas judges, like judges in the other 49 states, inevitably make law. Section III shows examples of Kansas judges making law. Section IV concludes that honesty requires lawyers participating in the debate over judicial selection in the United States to forthrightly acknowledge that judges make law. Lawyers who seek to defend the power advantage the Missouri Plan gives them over other citizens can honestly acknowledge that this is a power advantage in the selection of lawmakers and then explain why they believe a departure from the principle of one-person, one-vote is justified in the selection of these particular lawmakers. ${ }^{6}$

\section{THE STANDARD (“BALANCED REALIST") VIEW THAT JUDGES INEVITABLY MAKE LAW}

\section{A. Realism 101}

Judges are sometimes reluctant to acknowledge publicly that they inevitably make law. ${ }^{7}$ Why this reluctance? Perhaps because the notion that judges should not "legislate from the bench" 8 is popular among some segments of the public. ${ }^{9}$

This popularity is surely due, in part, to the efforts of originalists ${ }^{10}$ - those

6. For example, they might argue that judicial independence is better protected by the Missouri Plan than alternative systems. This argument is, I believe, is refuted by Ware, supra note 2 , at 751 n.2, 769-74.

7. Chief Justice Roberts, for example, likened judging to an umpire calling balls and strikes without, of course, playing the game. See Confirmation Hearing on the Nomination of John G. Roberts, Jr. to Be Chief Justice of the United States: Hearing Before the S. Comm. on the Judiciary, 109th Cong. 56 (2005) (statement of John G. Roberts) ("I will remember that it's my job to call balls and strikes, and not to pitch or bat.").

8. See, e.g., President George W. Bush, Address to the Nation Announcing the Nomination of John G. Roberts, Jr., To Be an Associate Justice of the United States Supreme Court, 41 WEEKLY COMP. PRES. DOC. 1192, 1192 (July 19, 2005) ("[Judge Roberts] will strictly apply the Constitution and laws, not legislate from the bench."); Todd E. Pettys, Judicial Retention Elections, The Rule of Law, and the Rhetorical Weaknesses of Consequentialism, 60 BUFF. L. REV. 69 (2012) ("prominent jurists do sometimes speak of adjudication as if it involved nothing more than the objective application of determinate rules").

9. Judge Richard Posner refers to "the allure [for judges] of being able to pose as a discerner rather than a creator of law, for that is the less controversial position and also flatters the laity's ignorant expectation of what a judge is supposed to do." RICHARD A. POSNER, HOW JUDGES THINK 262 (2008); James L. Gibson \& Gregory A. Caldeira, Has Legal Realism Damaged the Legitimacy of the U.S. Supreme Court?, 45 LAW \& SOC'Y REV. 195, 207 (2011) (finding that some Americans believe in "mechanical jurisprudence," but that this belief is not particularly widespread); John M. Scheb II \& William Lyons, The Myth of Legality and Public Evaluation of the Supreme Court, 81 SoC. SCI. Q. 928, 929 (2000) ("The myth of legality holds that cases are decided by the application of legal rules formulated and applied through a politically and philosophically neutral process of legal reasoning. [T]he myth of legality is deeply ingrained in American culture.").

10. On the connection between originalist scholarship and popular notions about the illegitimacy of judicial lawmaking, see, e.g., Thomas B. Colby, The Sacrifice of the New 
who contend that judges should interpret the U.S. Constitution's text as it was originally understood, rather than according to evolving social norms. For example, an organization that has done much to advance the cause of originalism, the Federalist Society, says "that it is emphatically the province and duty of the judiciary to say what the law is, not what it should be." 11 Under this view, roughly stated, if evolving social norms warrant constitutional change then those changes should be enacted through amendments to the constitution's text, ${ }^{12}$ rather than through the process of non-originalist judicial interpretation, which practically invites "activist" judges to convert their own policy preferences (political views) into law.

Yet even Justice Scalia, perhaps the leading originalist, "has repeatedly stated that judges 'make the law,' resolving policy issues in the process."13

Originalism, 99 GEO. L.J. 713, 777-78 (2011) (quoting Rush Limbaugh's praise for originalism); Justin Driver, Ignoble Specificities, THE NEw REPUBLIC, April 5, 2012, at 35 ("originalism has, in a shockingly short period of time, dramatically altered the terms of public constitutional discourse").

11. About Us, Our Background, THE FEDERALIST SOCIETY, http://www.fed-soc.org/ab outus/page/our-background (last visited Jan. 26, 2013). See also Marbury v. Madison, 5 U.S. (1 Cranch) 137, 177 (1803) ("It is emphatically the province and duty of the judicial department to say what the law is. Those who apply the rule to particular cases, must of necessity expound and interpret that rule. If two laws conflict with each other, the courts must decide on the operation of each."); THE FEDERALIST No. 78 (Alexander Hamilton) ("The courts must declare the sense of the law; and if they should be disposed to exercise WILL instead of JUDGMENT, the consequence would equally be the substitution of their pleasure to that of the legislative body.").

12. See, e.g., Renee Lettow Lerner, Enlightenment Economics and the Framing of the U.S. Constitution, 35 HARV. J.L. \& PUB POL'Y 37, 45 (2012) (“If the enumerated powers set out in the Constitution are thought to be too restrictive, the proper solution is to amend the Constitution, not to distort certain provisions beyond recognition. Although amendments to the Constitution have become very rare, in earlier times--when judges and other officials and citizens took the language of the Constitution more seriously--amendments were more frequent.").

13. Brian Z. Tamanaha, The Distorting Slant in Quantitative Studies of Judging, 50 B.C. L. REv. 685, 710 (2009) (citing ANTONIN SCALIA, Common Law Courts in a Civil Law System, in A MATTER OF INTERPRETATION: FEDERAL COURTS AND THE LAW 6, 9, 12 (Amy Gutmann ed., 1997)). See also Republican Party of Minn. v. White, 536 U.S. 765, 784 (2002) (Scalia, J.) ("Not only do state-court judges possess the power to 'make' common law, but they have the immense power to shape the States' constitutions as well. Which is precisely why the election of state judges became popular." (internal citation omitted)); James B. Bean Distilling Co. v. Georgia, 501 U.S. 529, 549 (1991) (Scalia, J., concurring in the judgment) ("I am not so naive (nor do I think our forebears were) as to be unaware that judges in a real sense 'make' law. But they make it as judges make it, which is to say as though they were 'finding' it-discerning what the law is, rather than decreeing what it is today changed to, or what it will tomorrow be. Of course this mode of action poses 'difficulties of a ... practical sort,' when courts decide to overrule prior precedent. But those difficulties are one of the understood checks upon judicial law-making; to eliminate them is to render courts substantially more free to 'make new law,' and thus to alter in a fundamental way the assigned balance of responsibility and power among the three branches." (internal citation omitted) (emphasis in original)); ANTONIN SCALIA, Common-Law Courts in a Civil-Law System: The Role of United States Federal Courts in Interpreting the Constitution and Laws, in A MATTER OF INTERPRETATION: FEDERAL COURTS AND THE LAW 10 (Amy Gutmann ed., 1997) ("It is only in this [20th] century, with the rise of legal realism, that we came to acknowledge that judges in fact 'make' the common law, and that each state has its own."). 
That judges make law does not much trouble Justice Scalia and other "great worriers over judicial usurpation" because they "typically draw a sharp distinction between constitutional judicial review and the common law process." ${ }^{14}$ In other words, activist judges injecting their policy preferences into constitutional law is deeply troubling to originalists, but activist judges injecting their policy preferences into the common law is not. ${ }^{15}$

This distinction follows from the premise that law should be made democratically. Democratic worries about judicial activism are far more severe when judges invoke a constitution to nullify statutes ${ }^{16}$ than when judges make common law, which can be overturned by statute. The common lawmade by judges ${ }^{17}$ - has served as the foundation of our law for centuries going back to England, ${ }^{18}$ but legislatures (now democratically-elected) can trump the

14. Benjamin Ewing \& Douglas A. Kysar, Prods and Pleas: Limited Government in an Era of Unlimited Harm, 121 YALE L.J. 350, 414 (2011).

15. Of course, originalists - like others - engage in a variety of different debates about how judges should make the common law. See infra note 20.

16. The practice of judges trumping statutes raises the "counter-majoritarian difficulty" that "continues to be an obsession of constitutional theorists." Kenneth Ward, The CounterMajoritarian Difficulty and Legal Realist Perspectives of Law: The Place of Law in Contemporary Constitutional Theory, 18 J.L. \& POL. 851, 851 (2002) (referring to "the countermajoritarian difficulty: how to justify judicial review, a non-democratic institution, in a government that derives its legitimacy from majority rule.") (citing ALEXANDER BICKEL, THE Least Dangerous Branch: The Supreme Court at the Bar of Politics, 16-18 (2d ed. 1986)). The opposite problem - judges declining to hold a statute unconstitutional because the statute embodies the judge's policy preferences - raises somewhat different concerns.

17. It is routine to treat the "common law" and "judge-made law" as equivalents. See Lueck v. Superior Court In \& For Cochise Cnty., 469 P.2d 68, 70 (Ariz. 1970), superseded by statute on other grounds, ARIZ. REV. STAT. ANN. § 12-612(C) ("When we find that the common law or 'judge-made law' is unjust or out of step with the times, we have no reluctance to change it."); Butcher v. Superior Court, 139 Cal. App. 3d 58, 64, (1983) ("When it is determined that the common law or judge-made law is unjust or out of step with the times, we have no reluctance to change it." (citing City of Glendale v. Bradshaw, 503 P.2d 803, 805 (Ariz. 1972)); Aluli v. Trusdell, 508 P.2d 1217, 1221 (Haw. 1973) (stating that "common law or judge-made law is the functional equivalent of statutory law”); Woodman v. Kera LLC, 785 N.W.2d 1, 21 (Mich. 2010) ("Given that the common law develops through judicial decisions, it has been described as “judge-made law."” (citing Placek v. Sterling Heights, 275 N.W.2d 511 (Mich. 1979)); Werner v. Hartfelder, 342 N.W.2d 520, 521 (Mich. 1984) ("the Court has recognized . . . that the common law is judge-made law ....").

18. See, e.g., Marie K. Pesando, 15A AM. JUR. 2D Common Law $\$ 3$ (2012) (“The common law migrated to this continent with the first English colonists, who claimed the system as their birthright; it continued in full force in the 13 original colonies until the American Revolution, at which time it was adopted by each of the states as well as the national government of the new nation. As new states were formed, they too adopted, by express provision or force of judicial decision, the principles of the common law insofar as applicable to their conditions." (internal citations omitted)); William D. Bader, Some Thoughts on Blackstone, Precedent, and Originalism, 19 VT. L. REV. 5, 5 (noting that "the English common law was the seminal influence on the formative generation of American lawyers."); NORMAN F. CANTOR, IMAGINING THE LAW: COMmon LAW AND the Foundations of the AMERICAN Legal System, 352-380 (1997) (explaining how the United States appropriated English common law as the basis of the its legal system); Daniel J. Boorstin, The Americans: The National ExPerience 35-42 (1965) 
common law by enacting statutes. ${ }^{19}$ And the ultimate trump card, the Constitution, is made by the highest lawmaking authority in a democratic society, the People themselves. Therefore, it is entirely consistent to want judges continuing to make the common law evolve to incorporate what the current generation of judges believes to be good policy, while forbidding judges from interpreting statutes and constitutions in that judge-emboldening way. ${ }^{20}$ In short, originalism's concerns about judicial activism focus on

(describing English common law as the foundation of America's legal system). For examples of reception statutes, see, e.g., Virginia General Convention Ordinance of May 6, 1776, ch. 5, § 6, 1776 Va. Colony Laws 33, 37 ("And be it further ordained, that the common law of England, all statutes and acts of Parliament made in aid of the common law prior to the fourth year of the reign of King James the first [1607], and which are of a general nature, not local to that kingdom, together with the several acts of the General Assembly of this colony now in force, so far as the same may consist with the several ordinances, declarations and resolutions of the General Convention, shall be the rule of decision, and shall be considered as in full force, until the same shall be altered by the legislative power of this colony."); MO. REV. STAT. § 1.010 (2000) ("The common law of England and all statutes and acts of parliament made prior to the fourth year of the reign of James the First, of a general nature, which are local to that kingdom and not repugnant to or inconsistent with the Constitution of the United States, the constitution of this state, or the statute laws in force for the time being, are the rule of action and decision in this state, any custom or usage to the contrary notwithstanding").

19. See, e.g., Marie K. Pesando, 15A AM. JuR. 2D Common Law § 10 (2012) (“The English common law has been adopted as the basis of jurisprudence in all the states of the Union with the exception of Louisiana, where the civil law prevails in civil matters. The common law prevails generally throughout the United States, except as modified, changed, or repealed by statute or constitutional provisions of an individual state"); John F. Duffy, Administrative Common Law in Judicial Review, 77 TEX. L. REV. 113, 116 (1998) ("[L]egislators are the lawgivers ... [and so] courts deciding statutory cases are bound to follow commands and policies embodied in the enacted text - commands and policies the courts did not create and cannot change."); Richard A. Posner, Legal Formalism, Legal Realism, and the Interpretation of Statutes and the Constitution, 37 CASE W. RES. L. REV. 179, 189 (1986) ("In our system of government the framers of statutes... are the superiors of the judges. The framers communicate orders to the judges through legislative texts. . . . If the orders are clear, the judges must obey them."); Cass R. Sunstein, Interpreting Statutes in the Regulatory State, 103 HARV. L. REV. 405, 415 (1989) (“According to the most prominent conception of the role of courts in statutory construction, judges are agents or servants of the legislature. . . The judicial task is to discern and apply a judgment made by others, most notably the legislature.").

20. See Antonin Scalia, Common-Law Courts in a Civil-Law System: The Role of United States Federal Courts in Interpreting the Constitution and Laws, in A MATTER OF INTERPRETATION: FEDERAL COURTS AND THE LAW 3, 12 (Amy Gutmann ed., 1997) (praising the common law method: "It has proven to be a good method of developing the law in many fields and perhaps the very best method."); . at 38 (defending "original meaning" constitutional interpretation against "The Living Constitution").

The ascendant school of constitutional interpretation affirms the existence of what is called The Living Constitution, a body of law that (unlike normal statutes) grows and changes from age to age, in order to meet the needs of a changing society. And it is the judges who determine those needs and "find" that changing law. Seems familiar, doesn't it? Yes, it is the common law returned, but infinitely more powerful than what the old common law ever pretended to be, for now it trumps even the statutes of democratic legislatures.

Id. at 38 
constitutional and statutory cases and are no obstacle to acknowledging that judges inevitably make the common law. ${ }^{21}$

The acknowledgment that judges inevitably make the common law became routine with the growth, and then dominance, of legal realism, over the course of the last century. ${ }^{22}$ While the Legal Realists had many, and sometimes divergent, views, their "most basic insight" is "that common-law judges make public policy in deciding cases no less than legislators do in enacting laws." ${ }^{23}$ Like most everyone else, Justice Scalia says that it was with

21. Of course, originalists - like others - engage in a variety of different debates about how judges should make the common law. One of these debates is the pace at which the common law should evolve. Perhaps originalist judges tend to be conservative and perhaps conservative judges generally have a Burkean or Hayekian respect for longstanding common law as embodying the accumulated wisdom gained from many generations of trial-and-error experience. See, e.g., Todd J. Zywicki \& Anthony B. Sanders, Posner, Hayek, and the Economic Analysis of Law, 93 IowA L. REV. 559, 582 (2008) ("Hayek shares the traditional view that cases are merely illustrations of more abstract legal principles; cases are not 'law' in and of themselves. The independent efforts of many judges deciding many cases over time generates legal principles, and it is those principles that matter, not the constituent cases themselves. The legal principles that emerge from this implicit collaboration among many judges reflect greater wisdom and consensus than any individual judge deciding any individual case. Thus, it is that Hayek characterizes the common law as a spontaneous order in the same way that the market is a spontaneous order.") Perhaps such judges tend to subordinate their own policy preferences to the policies already embodied in the common law and thus hew closely to precedents, resulting in a common law that evolves slowly and cautiously. In contrast, progressive judges may tend to see longstanding common law less positively and thus be more willing to replace it with new law reflecting the policy preferences of current judges, resulting in a common law that evolves more rapidly.

22. "In the early part of the twentieth century, the hard-headed and clear-eyed Justice Holmes, the leader of the legal realists, insisted that it was a myth that judges decided controversial cases by 'finding' rather than making the law. That contention was a step in the direction of a more mature and honest legal system." Lino A. Graglia, Originalism and the Constitution: Does Originalism Always Provide the Answer?, 34 HARV. J.L. \& PUB. POL'Y 73, 84-85 (2011); see also Charles Gardner Geyh, Straddling the Fence Between Truth and Pretense: The Role of Law and Preference in Judicial Decision Making and the Future of Judicial Independence, 22 Notre DAME J.L. ETHICS \& PUB. POL'Y 435, 438 (2008) (“The legal realism movement of the 1920s challenged the traditional view that judges were essentially value-neutral automatons who mechanically divined and applied the true meaning of the law. Rather, legal realists asserted that judges are influenced by their education, upbringing, ambitions, experiences, and values to no less an extent than anyone else."); Frederick Schauer, Do Cases Make Bad Law?, 73 U. CHI. L. REV. 883, 886 (2006) ("Now, having for generations bathed in the teachings of Holmes and the Realists, we heed their lessons. We no longer deny the creative and forwardlooking aspect of common law decisionmaking [sic], and we routinely brand those who do as 'formalists.' It is thus no longer especially controversial to insist that common law judges make law.").

23. David L. Franklin, Justice Ginsburg's Common-Law Federalism, 43 New EnG. L. REV. 751, 757 (2009); see also George D. Brown, Political Judges and Popular Justice: A Conservative Victory or a Conservative Dilemma?, 49 WM. \& MARY L. REV. 1543, 1601 (2008) ("Common law courts are certainly engaged in the business of making law and policy. . . . [A]nyone who contends otherwise is falling into the trap of magisterial visions of the judiciary that have been discredited by legal realism and the work of political scientists.") (citing Michael R. Dimino, Pay No Attention to That Man Behind the Robe: Judicial Elections, the First Amendment, and Judges as Politicians, 21 YALE L. \& POL'Y ReV. 301, 357-67 (2003)); David 
the 20th Century rise of legal realism "that we came to acknowledge that judges in fact 'make' the common law." 24

Realism about judicial lawmaking is not, however, confined to the common law. ${ }^{25}$ As nearly everyone (including Justice Scalia ${ }^{26}$ ) recognizes, statutory language is sometimes vague or ambiguous. ${ }^{27}$ Such statutes do not

Luban, Justice Holmes and the Metaphysics of Judicial Restraint, 44 DuKE L.J. 449, 504 (1994) ("[T] he fundamental insight of [Holmes's] legal realism is that judges can make and unmake law (though they customarily deny that this is what they are doing) . . .."); John Hasnas, The Depoliticization of Law, 9 THEORETICAL INQUIRIES L. 529, 543 (2008) ("“T]he legal realists established that the rules of law do not bind common law judges to decide controversial appellate cases one way rather than another. The existence of contradictory rules of law and construction and the open textured nature of legal language always provide the judge sufficient leeway to arrive at the legal conclusion that he or she believes to be correct - something that is determined by his or her pre-existing moral and ideological commitments.").

24. "It is only in this [20th] century, with the rise of legal realism, that we came to acknowledge that judges in fact 'make' the common law, and that each state has its own." Antonin Scalia, Common-Law Courts in a Civil-Law System: The Role of United States Federal Courts in Interpreting the Constitution and Laws, in A MATTER OF INTERPRETATION: FEDERAL COURTS AND THE LAW 10 (Amy Gutmann ed., 1997). Brian Tamanaha's more detailed and nuanced histories suggest that realism actually predated the Realists, that is, 19th Century judges were aware that they were making law. See generally Brian Z. Tamanaha, Balanced Realism on Judging, 44 VAL. U. L. REV. 1243 (2010); BRIAN Z. TAMANAHA, BEYOND THE FORMALISTReAlist Divide: The Role of Politics IN Judging 18-20 (2009) (in the late $19^{\text {th }}$ Century, "[e]ven judges openly acknowledged that they made law."); Brian Z. Tamanaha, Understanding Legal Realism, 87 TEX. L. REV. 731 (2009).

25. "The Core Claim of Legal Realism consists of the following descriptive thesis about judicial decision-making: judges respond primarily to the stimulus of facts. Put less formallybut also somewhat less accurately - the Core Claim of Realism is that judges reach decisions based on what they think would be fair on the facts of the case, rather than on the basis of the applicable rules of law." Brian Leiter, Rethinking Legal Realism: Toward a Naturalized Jurisprudence, 76 TEX. L. REV. 267, 275 (1997).

26. See W. Va. Univ. Hosps., Inc. v. Casey, 499 U.S. 83, 100-01 (1991) (Scalia, J.), superseded by statute on other grounds, 42 U.S.C. § 1988(c) (2000) ("Where a statutory term presented to us for the first time is ambiguous, we construe it to contain that permissible meaning which fits most logically and comfortably into the body of both previously and subsequently enacted law. We do so not because that precise accommodative meaning is what the lawmakers must have had in mind (how could an earlier Congress know what a later Congress would enact?), but because it is our role to make sense rather than nonsense out of the corpus juris.") (internal citations omitted); BFP v. Resolution Trust Corp., 511 U.S. 531, 547 (1994) (Scalia, J.) ("the 'plain meaning' of [the statutory language] 'reasonably equivalent value' continues to leave unanswered the one question central to this case, wherein the ambiguity lies: What is a foreclosed property worth? Obviously, until that is determined, we cannot know whether the value received in exchange for foreclosed property is 'reasonably equivalent.' We have considered three possible answers to this question-fair market value.") (parenthetical omitted); Antonin Scalia, The Rule of Law as a Law of Rules, 56 U. CHI. L. REV. 1175, 1183 (1989) ("One can hardly imagine a prescription more vague than the Sherman Act's prohibition of contracts, combinations or conspiracies in restraint of trade.").

27. On the distinction between vague and ambiguous, see E. Allan Farnsworth, "Dmeaning" in the Law of Contracts, 76 YALE L.J. 939, 953 (1967) ("Ambiguity, properly defined, is an entirely distinct concept from that of vagueness. A word that may or may not be applicable to marginal objects is vague. But a word may also have two entirely different connotations so that it may be applied to an object and be at the same time both clearly 
compel a single result in each case that might arise, as reasonable people can disagree about the best interpretation of the statute and, therefore, the best result of the particular case. "The legal realists saw the interpretation of statutory ambiguities as necessarily involving judgments of policy and principle. They insisted that when courts understand statutes to mean one thing rather than another, they use judgments of their own, at least in genuinely hard cases." 28 This realist view that statutory interpretation often involves "substantial judicial discretion" and therefore constitutes "judicial lawmaking, not lawfinding," had by the 1950s, "become deeply rooted." 29

These realist points about judicial lawmaking in statutory interpretation apply as well to judicial lawmaking in constitutional interpretation. That constitutional provisions are sometimes vague or ambiguous is acknowledged by just about everyone, including prominent originalists like Randy Barnett, who explains as follows.

[O]riginalism is a method of constitutional interpretation that identifies the meaning of the text as its public meaning at the time of its enactment. The text of the Constitution may say a lot, but it does not say everything one needs to know to resolve all possible cases and controversies. Originalism is not a theory of what to do when original meaning runs out. This is not a bug; it is a feature. Were a constitution too specific, its original meaning probably would become outdated very quickly. A constitution with a degree of vagueness delegates some decisions of application to the judgment of future actors, provided these decisions do not conflict with the information that is provided by the text. ${ }^{30}$

appropriate and inappropriate, as the word 'light' may be when applied to dark feathers. Such a word is ambiguous.").

28. Cass R. Sunstein, Beyond Marbury: The Executive's Power to Say What the Law Is, 115 YALE L.J. 2580, 2591 (2006). The classic is perhaps Karl Llewellyn's legal-realist critique of statutory interpretation showing that the canons of construction are often inconsistent. See Karl N. Llewellyn, Remarks on the Theory of Appellate Decisions and the Rules or Canons About How Statutes Are To Be Construed, 3 VAND. L. ReV. 395 (1950); see also M. R. CoHEN, The Process of Judicial Legislation, in LAW AND THE SOCIAL ORDER 112-13, 121-24 (1933), reprinted in COHEN AND COHEN'S READINGS IN JURISPRUDENCE AND LEGAL PHILOSOPHY 241 (Philip Shuchman ed., 2d ed., 1979) ("[N]ot only is the common law changed from time to time by judicial decisions ... the courts also make our statute law; for it is the court's interpretation of the meaning of a statute that constitutes the law.").

29. Philip P. Frickey, From the Big Sleep to the Big Heat: The Revival of Theory in Statutory Interpretation, 77 MINN. L. REV. 241, 248 (1992) ("Because neither statutory text nor legislative intent was universally determinate and confining, the legal realists insisted that statutory interpretation often involved substantial judicial discretion and constituted judicial lawmaking, not law finding. ... By the 1950s, the legal realists' critique of interpretive formalism had become deeply rooted."); Paul D. Carrington \& Adam R. Long, The Independence and Democratic Accountability of the Supreme Court of Ohio, 30 CAP. U. L. REV. 455, 469 (2002), ("Although there was a time in the late nineteenth and early twentieth centuries when many American lawyers and some citizens deluded themselves with the belief that judges could be trained to be professional technicians interpreting statutes and constitutions without regard to their political consequences, there is virtually no one who thinks that today.").

30. Randy E. Barnett, Interpretation and Construction, 34 HARV. J.L. \& PUB. POL'Y 65, 69- 
To the same effect are the writings of another well-known originalist, Steven Calabresi ${ }^{31}$ Chairman of the Federalist Society. ${ }^{32}$ After noting that the United States Constitution consists not only of rules, but also of standards and principles ${ }^{33}$ Professor Calabresi says "[a]dopters use rules because they want to limit discretion; they use standards or principles because they want to channel politics but delegate the details to future generations." ${ }^{34}$ While rules are relatively determinate, with respect to at least some standards, "different reasonable constitutional interpreters will differ on how the standard should be applied." 35

Do these differences among reasonable constitutional interpreters (judges) correlate with the judges' policy preferences? The consensus is that they do, especially at the supreme court level. Most everyone "recognize[s] that the constitutional opinions of Supreme Court Justices are affected by their political proclivities." ${ }^{36}$ Even Justice Scalia acknowledges that high-court judges have "immense power to shape" constitutions. ${ }^{37}$ As Suzanna Sherry puts it, "[s]ince at least the time of the Legal Realists, lawyers, judges, and legal scholars have recognized that judges do make law, especially in cases that are difficult or ambiguous enough to require Supreme Court adjudication." 38 In sum, "[t]he insights of legal realism have important consequences for constitutional law. If legal doctrine can no longer be counted on to insulate judicial decisions from the normative preferences of the judges who render them, the constitutional

70 (2011).

31. See Steven G. Calabresi \& Julia T. Rickert, Originalism and Sex Discrimination, 90 Tex. L. Rev. 1, 16 (2011) (referring to the "undeniable ambiguity" of Section 1 of the Fourteenth Amendment); Steven G. Calabresi \& Sarah E. Agudo, Individual Rights Under State Constitutions when the Fourteenth Amendment was Ratified in 1868: What Rights are Deeply Rooted in American History and Tradition?, 87 TEX. L. REV. 7, 81 (2008) ("One ambiguity of the Cruel and Unusual Punishment Clause is whether it forbids all disproportionate punishments or only a certain set of punishments that were thought to be cruel and unusual 200 years ago, like drawing and quartering."); Steven G. Calabresi, Text, Precedent, and the Constitution: Some Originalist and Normative Arguments for Overruling Planned Parenthood of Southeastern Pennsylvania v. Casey, 22 Const. Comment. 311, 328 (2005) (stating that precedent should be given determinative weight in constitutional cases only where "the text is vague and all three branches of the federal government are content with" governing precedent).

32. About Us, Board of Directors, THE FEDERALIST SOCIETY, http://www.fed-soc.org/abou tus/page/board-of-directors (last visited Jan. 26, 2013).

33. Steven G. Calabresi \& Livia Fine, Two Cheers for Professor Balkin's Originalism, 103 Nw. U. L. REV. 663, 672 (2009).

34. Id.

35. Id. at 673. This reasonable-people-can-disagree point is even stronger with respect to constitutional principles, which are even less determinate than constitutional standards.

36. Jack Goldsmith \& Daryl Levinson, Law for States: International Law, Constitutional Law, Public Law, 122 HARV. L. ReV. 1791, 1834 (2009).

37. See Republican Party of Minn. v. White, 536 U.S. 765, 784 (2002) ("Not only do statecourt judges possess the power to 'make' common law, but they have the immense power to shape the States' constitutions as well. Which is precisely why the election of state judges became popular." (internal citation omitted)).

38. Suzanna Sherry, The Four Pillars of Constitutional Doctrine, 32 CARDOZO L. REV. 969, 974 (2011). 
law that is being announced by judges will ultimately be shaped by the normative values of the judges themselves." 39

\section{B. Balanced Realism and the Multifaceted Role of a Judge}

To recap, it is a "truism that judges make law." 40 That "we are all realists now" is so thoroughly accepted as to be a cliche. ${ }^{41}$

Of course, this does not mean that each branch of governmentlegislative, executive and judicial— plays an equally large role in making law (as distinguished from applying and enforcing law). As noted above, the common law is an important realm for judicial lawmaking, but whatever law judges make in this realm can be overturned by the other two branches, through enactment of a statute. And even when the other branches leave an area of lawmaking to the judiciary, the common law process tends to minimize the extent to which any individual judge's policy preferences become law. The common law evolves one case at a time and following precedent is the norm, so major changes in the common law tend to require sustained consensus of many judges across time. ${ }^{42}$ In contrast, major changes in statutory and

39. Girardeau A. Spann, Constitutionalization, 49 St. LoUIS U. L.J. 709, 714 (2005).

40. "Post-realist jurisprudence must depart from the truism that judges make law and begin instead with the question of how they make law." See Neil Duxbury, Faith in Reason: The Process Tradition in American Jurisprudence, 15 CARDOZO L. REV. 601, 636 (1993).

41. Leiter, supra note 25, at 267; see also Charles Gardner Geyh, Straddling the Fence Between Truth and Pretense: The Role of Law and Preference in Judicial Decision Making and the Future of Judicial Independence, 22 NOTRE DAME J.L. ETHICS \& PUB. POL'Y 435, 438, 444 (2008) ("In an age when '[w]e are all legal realists now,' it is too late in the day to pretend that when judges adjudicate disputes between adversaries, both of whom support their positions with credible-seeming legal arguments, the value preferences of the judges never factor into the choices they make."); Thomas W. Merrill, High-Level, "Tenured" Lawyers, 61 LAW \& CONTEMP. PROBS. 83, 88 (1998) ("We live in a post-Legal Realist Age, when most legal commentators take it for granted that law cannot be disentangled from politics and that legal judgment is driven by the political beliefs of the decision maker."); Gary Peller, The Metaphysics of American Law, 73 CALIF. L. REV. 1151, 1152 (1985) ("It is a commonplace that law is 'political."'); Jerry Elmer, Legal Realism, Legal Formalism and the D'Oench Duhme Doctrine: A Perspective on R.I. Depositors Econ. Prot. Corp. v. NFD, 53 R.I. B.J. 9, 11 (2004) ("Today, we are all Legal Realists. Being Realists, we understand two things: that judges do make law, not just find it, and that public policy considerations may properly enter into a judge's deliberations."); MORTON J. HORWITZ, THE TRANSFORMATION OF AMERICAN LAW, 1870-1960, 169-212 (1992) (legal realism's most important legacy was its challenge to the notion that law has an autonomous role separate from politics); Michael C. Dorf \& Charles F. Sabel, A Constitution of Democratic Experimentalism, 98 COLUM. L. REV. 267, 274 (1998) ("[T]he program of unmasking law as politics [was] central to American Legal Realism ....”).

42. Randy E. Barnett, Foreword: Judicial Conservatism v. A Principled Judicial Activism, 10 HARV. J.L. \& PUB. POL'Y 273, 286-87 (1987) ("The judicially-driven common law system develops substantive standards that are as much a product of collective wisdom as the statutory output of Congress, perhaps more. With the many real constraints a common law system places on judges, it is perhaps astounding that any evolution of law actually occurs, that creative judicial 'lawmaking' (beyond individual cases) exists at all. Maybe this is why the progress of the common law has sometimes seemed to be so painfully slow."); GUIDO CALABRESI, A COMMON LAW FOR THE AGE OF STATUTES 4 (1982) (“The incremental nature of common law adjudication 
regulatory law can occur quickly, and this is especially likely to occur when the same political party gains control of the legislative and executive branches. $^{43}$

Shifting our focus from common law cases to statutory and regulatory cases, we again see that realism about judicial lawmaking does not imply that the content of legal rules is determined as much by judges' policy preferences as by the policy preferences of those leading the other two branches of government. Judicial deference to the enactments of the legislative and executive branches is the norm ${ }^{44}$, and judicial interpretation of these enactments generally occurs in the context of adjudicating a dispute that has already arisen between particular parties ${ }^{45}$ so this fact-specific context tends to minimize the extent to which any individual judge's policy preferences

meant that no single judge could ultimately change the law, and a series of judges could only do so over time and in response to changed events or to changed attitudes in the people."); Deborah A. Widiss, Undermining Congressional Overrides: The Hydra Problem in Statutory Interpretation, 90 TEX. L. REV. 859, 867 (2012) ("[N]otwithstanding respect for precedent, common law courts reconsider prior precedents in response to changing needs or evolving norms; often, this occurs gradually as prior decisions are distinguished and new decisions slowly accumulate until ultimately a high court announces a new rule."); Andrew J. Wistrich, The Evolving Temporality of Lawmaking, 44 CONN. L. REV. 737, 781 (2012) ("While common law decision-making proceeds incrementally ... statutory change, though more difficult to achieve, can be avulsive.").

43. "Social scientists have found that important and noteworthy laws are far more likely to emerge when the same political party controls both Congress and the executive branch; a divided government, in contrast, impairs the lawmakers' ability to enact consequential law." Lee Epstein, Barry Friedman, \& Nancy Staudt, On the Capacity of the Roberts Court to Generate Consequential Precedent, 86 N.C. L. REv. 1299, 1332 n.39 (2008). Judge-made law can change significantly in the year or two following a change in the political party or interest group in control of the judicial branch. See Stephen J. Ware, Money, Politics and Judicial Decisions: A Case Study of Arbitration Law in Alabama, 15 J.L. \& POL. 645, 656-60 \& n.78 (1999) (1998 shift in Alabama Supreme Court's majority from Democrats receiving campaign contributions primarily from plaintiffs' trial lawyers to Republicans receiving campaign contributions primarily from businesses "marked a major turning point. Cases that plaintiffs had previously won fivevotes-to-four now turned into defendant victories by the same margin"); Id. at 684 ("[A]rbitration cases indicate that the court often splits along predictable, and highly partisan, lines. Justices whose campaigns are funded by plaintiffs' lawyers are all Democrats and oppose arbitration, while justices whose campaigns are funded by business are nearly all Republicans and favor arbitration. There is a strong correlation between a justice's source of campaign funds and how that justice votes in arbitration cases."); id. at 685 ("Arbitration law in Alabama seems to have no doctrinal integrity that survives the vicissitudes of the interest group battle. This law is indeed politics, in a very real and direct sense. This law provides evidence for the strong strain of Legal Realism which 'contends that law is politics through and through and that judges exercise broad discretionary authority."').

44. See supra note 19.

45. See, e.g., George D. Brown, Political Judges and Popular Justice: A Conservative Victory or a Conservative Dilemma?, 49 WM. \& MARY L. REV. 1543, 1560, 1603-04 (2008); Paul Carrington, Judicial Independence and Democratic Accountability in Highest State Courts, 61 LAW \& CONTEMP. PROBS. 79, 91-92 (1998) ("A fundamental difference exists between judicial and legislative offices ... because judges decide the rights and duties of individuals even when they are making policy[.]"). 
become law. ${ }^{46}$

In sum, the realist truism that "judges make law" is very different from a claim that all judicial decisions consist entirely of the judge's political views. A "balanced realism," to use Brian Tamanaha's appealing label, ${ }^{47}$ recognizes both that judges' policy preferences have little or no influence on many judicial decisions and that judges' policy preferences have a significant influence on other judicial decisions. Empirical studies tend to support this balanced view. ${ }^{48}$ As Tamanaha puts it, "[i]n a well-functioning legal system,

46. James B. Bean Distilling Co. v. Georgia, 501 U.S. 529, 549 (1991) (Scalia, J., concurring) ("I am not so naive (nor do I think our forebears were) as to be unaware that judges in a real sense "make" law. But they make it as judges make it, which is to say as though they were 'finding' it-discerning what the law is, rather than decreeing what it is today changed to, or what it will tomorrow be. Of course this mode of action poses 'difficulties of a ... practical sort,' when courts decide to overrule prior precedent. But those difficulties are one of the understood checks upon judicial law-making; to eliminate them is to render courts substantially more free to 'make new law,' and thus to alter in a fundamental way the assigned balance of responsibility and power among the three branches.").

47. Brian Z. Tamanaha, Balanced Realism on Judging, 44 VAL. U. L. REV. 1243, 1258-59 (2010).

48. As Charles Gardner Geyh summarizes, "influences on judicial decision-making are complex and multivariate." CHARLES GARDNER GEYH, WHAT's LAW GOT TO DO WITH IT? What Judges Do, Why They Do It, And What's At Stake 3 (2011). Accord Charles Gardner Geyh, Can the Rule of Law Survive Judicial Politics?, 97 CORNELL L. REv. 191, 206-14 (2012) (summarizing empirical studies of judicial behavior by political scientists and legal scholars); see also Frank B. Cross, Decisionmaking in the U.S. Circuit Courts of Appeals, 91 CALIF. L. REV. 1457, 1482 (2003) ("The weight of the empirical evidence clearly reveals some role for ideology in judicial decisionmaking. As Charles Songer and others have articulated, ' $[t]$ he general picture presented by these studies is clear: across a wide variety of courts and issue areas, Democratic judges are more likely to support the liberal position in case outcomes than their Republican colleagues.' The evidence for the political model is 'abundant and convincing.' But while the empirical evidence on the political model may conflict with the legal model, it is not so strong as to demonstrate that the legal model has no practical importance."); Ward Farnsworth, Signatures of Ideology: The Case of the Supreme Court's Criminal Docket, 104 MICH. L. REV. 67, 71 (2005) ("The better interpretation [of the data] is that every case provokes competition between a justice's preferences on the one hand and the legal materials on the other. When the legal materials are very strong, they can produce unanimity despite conflicting preferences. But when the legal materials aren't so strong - when they don't point to a clear answer and leave room for discretionary judgment - the competition is won by the justice's underlying preferences and views of the world.”); Gregory C. Sisk \& Michael Heise, Judges and Ideology: Public and Academic Debates About Statistical Measures, 99 Nw. U. L. REV. 743. 77172 (2005) ("[W]hile the basic empirical finding that political ideology explains some of the variation among judges in reaching an answer in certain categories of court cases cannot be denied, neither should the influence of the ideological variable be overstated. Review of recent studies in terms of the actual margin of difference between judges of different political associations suggests the effect of this variable is more often moderate than large."); Corey Rayburn Yung, Judged by the Company You Keep: An Empirical Study of the Ideologies of Judges on the United States Courts of Appeals, 51 B.C. L. REv. 1133, 1143 (2010) ("Even the most ardent supporters of strategic and legal models of decision making acknowledge that a portion of decisions are best explained by ideology.").

Caution about empirical studies of judges' ideologies, attitudes and policy preferences is warranted because 
judges largely abide by and apply the law, there are practice-related, social and institutional factors that constrain judges and judges render generally predictable decisions consistent with the law."49 However, it is equally true "that judges sometimes make choices, that they can manipulate legal rules and precedents, and that they sometimes are influenced by their political views and personal biases." 50 Tamanaha explains that, "the legal realists viewed judging in similarly balanced terms. They did not assert that judges routinely manipulated the law to produce desired outcomes." ${ } 51$ As Judge Richard Posner notes, successful reconciliation of legal realism "with the undoubted fact that there is a fair degree of predictability" in the law occurred at least as long as ago as $1960 . .^{52}$

To reiterate, the realist truism that "judges make law" is very different from a claim that all judicial decisions consist entirely of the judge's political views. Perhaps most, or even all, judges usually succeed in subordinating their policy preferences to those of some other lawmaker, such as the legislature that enacted the relevant statute ${ }^{53}$ or the higher court that decided the relevant case

[t]hese beliefs, like any other beliefs, are concealed inside the believer's head. . . . Because a judge's attitude can never be known to anyone but the judge, political scientists have had to use other data as proxies for 'attitude.' Such data include: party affiliation, background experiences and social characteristics, prior votes, speeches, and newspaper editorials.

Stephen J. Ware, Money, Politics and Judicial Decisions: A Case Study of Arbitration Law in Alabama, 15 J.L. \& POL. 645, 648 (1999). Therefore, it is more careful to say that judges' rulings in a particular category of cases correlate with the judge's political party, for example, than with the judge's ideology or policy preferences. See generally Joshua B. Fischman \& David S. Law, What is Judicial Ideology, and How Should We Measure It?, 29 WASH. U. J.L. \& POL'Y 133 (2009).

Different measures of ideology vary greatly in their ability to explain judicial voting, and .... the choice of one measurement approach over another can significantly influence the findings that scholars reach. If empirical scholarship involving the concept of judicial ideology is to realize its scientific potential or gain greater acceptance from a wider audience, those of us who produce such scholarship must learn both to speak clearly about what is meant by "judicial ideology," and to give careful thought to the methods that are employed to measure it.

$I d$. at 213-14. On the challenges of measuring case outcomes, see Tonja Jacobi \& Matthew Sag, Taking the Measure of Ideology: Empirically Measuring Supreme Court Cases, 98 GEO. L.J. 1 (2009).

49. Tamanaha, supra note 47 , at 1258-59.

50. Id. See also Brian Z. TAmanaha, Beyond the Formalist-Realist Divide: The Role OF POLITICS IN JUdGING 6 (2010).

51. See also Leiter, supra note 25 , at 268 ("it is . . quite misleading to think of Realism as committed to the claim that judges exercise 'unfettered' discretion"); id. at 273 ("the Realists, unlike [Critical Legal Studies] writers, did not generally view the law as 'globally' indeterminate, that is, as indeterminate in all cases. To the contrary, Realists were mainly concerned to point out the indeterminacy that exists in those cases that are actually litigated, especially those that make it to the stage of appellate review - a far smaller class of cases, and one where indeterminacy in law is far less surprising.").

52. PoSner, supra note 9, at 213 (citing KARL Llewellyn, The COMmon LaW TRADITION: DECIDING APPEALS (1960)).

53. See sources cited supra note 19. 
law precedents. ${ }^{54}$ However, even if most cases are unaffected by the judge's political views, the standard, realist view that "judges make law" nevertheless rests securely on the premise that some judicial decisions - perhaps the "hard cases" (Ronald Dworkin ${ }^{55}$ ) or the "penumbral cases" (H.L.A. Hart ${ }^{56}$ )—are, to some extent, affected by judges' political views. ${ }^{57}$ Only someone far outside the mainstream of our country's 20th and 21st Century legal thought would seriously dispute that premise. "In a post-realist age," as Charles Gardner Geyh says, "the ideological orientation of judicial aspirants matters." 58

To put it another way, it is well established that judging has both a professional/technical side and a political/lawmaking side. ${ }^{59}$ The

54. See infra notes 61-62 and accompanying text.

55. Ronald Dworkin, Hard Cases, 88 HARV. L. REv. 1057, 1060 (1975) (defining "hard cases" as those in which "no settled rule dictates a decision either way").

56. H.L.A. Hart, Positivism and the Separation of Law and Morals, 71 HARV. L. REV. 593 (1958).

A legal rule forbids you to take a vehicle into the public park. Plainly this forbids an automobile, but what about bicycles, roller skates, toy automobiles? . . . [T] he general words we use - like "vehicle" in the case I consider - must have some standard instance in which no doubts are felt about its application. There must be a core of settled meaning, but there will be, as well, a penumbra of debatable cases in which words are neither obviously applicable nor obviously ruled out.

$* * *$

We may call the problems which arise outside the hard core of standard instances or Id. at 607 . settled meaning "problems of the penumbra"; they are always with us ....

57. See, e.g., Todd E. Pettys, Judicial Retention Elections, The Rule of Law, and the Rhetorical Weaknesses of Consequentialism, 60 BUFF. L. REV. 69 (2012).

There are, of course, instances in which judges do little more than apply the plain requirements of the law, as when a case calls for the application of unambiguous thresholds (like ages and speed limits) or when a dispute plainly falls within a welldeveloped line of uncontested and homogeneous precedent. [In contrast,] matters like abortion, same-sex marriage, and the rights of criminal defendants [are] matters governed by legal texts whose open- ended wording is reasonably susceptible to competing interpretations. When the relevant legal texts speak at a high level of abstraction, or when the identification of the relevant legal texts is itself contested, judges must — by necessity - exercise interpretive discretion. This does not mean that judges are free to select any outcomes and rationales that suit their fancy. Rather, it means that in cases of the sort that are likely to trigger public controversy, there often are multiple ways in which a judge who conscientiously applies the interpretive conventions of the legal profession could resolve the given dispute.

Id. at 101-02 (internal quotation marks omitted). See also Adam M. Samaha, On Law's Tiebreakers, 77 U. CHI. L. REV. 1661, 1710 (2010) (“[I]t is conventional wisdom to believe that many interpretive issues are resolved by conventional legal argument while a more difficult set of controversies - perhaps made unavoidable by selection effects in litigation - are influenced by judicial discretion or ideology.”).

58. Charles Gardner Geyh, Judicial Selection Reconsidered: A Plea for Radical Moderation, 35 HARV. J.L. \& PUB. POL’y 623, 638 (2012).

59. For this reason, "When discussing appointments to the Bench, we distinguish different kinds of desirable characteristics judges should possess. We value their knowledge of the law and their skills in interpreting laws and in arguing in ways showing their legal experience and expertise. We also value their wisdom and understanding of human nature, their moral 
professional/technical side may include applying to the facts of a case, law made by someone other than the judge (e.g., a legislature,) as well as running a courtroom and so forth. But judging also involves lawmaking, the political side highlighted by the Legal Realists. "Just as it is one-sided to denigrate the technical, lawyerly side of judging by claiming that judges are simply 'politicians in robes,' it is also one-sided to denigrate the lawmaking side of judging by claiming that the political views of a judge are irrelevant to his or her job as a judge." 60

The political/lawmaking side of judging looms larger, the higher the court. In other words, the extent to which (inevitable) judicial lawmaking allows judges to inject their political views into law rises, the higher the court. Trial judges play less of a lawmaking role than appellate judges, especially supreme court justices, simply because court systems are hierarchical and trial courts are at the bottom. ${ }^{61}$ The legal rulings of trial courts can be reversed, de novo, by appellate courts. ${ }^{62}$ In contrast, appellate courts are often the final word, as a practical matter, on issues of law. Appellate courts' common law rulings can be overturned by statute, but enacting any legislation requires overcoming the inertia of a legislature with many issues competing for its attention. Similarly, overcoming that inertia is also needed to overturn judicial interpretations of statutes. This inertia point is even stronger with respect to judicial decisions interpreting constitutions. These decisions can be overturned, not by statute, but by constitutional amendment. Unless and until

sensibility, their enlightened approach, etc.” JOSEPH RAZ, THE AUTHORITY OF LAW: ESSAYS ON LAW AND MORALITY 48 (1979).

60. Ware, supra note 2, at 757 (citing David R. Stras \& Ryan W. Scott, Navigating the New Politics of Judicial Appointments, 102 Nw. U. L. REV. 1869, 1871 (2008) (describing "two popular narratives about the way Supreme Court Justices decide cases: one that treats Justices as neutral and nonpolitical 'umpires,' and another that views Justices as pervasively ideological 'politicians' in robes."); Roy A. Schotland, To the Endangered Species List, Add: Nonpartisan Judicial Elections, 39 WiLlameTte L. REv. 1397, 1419 (2003) (referring "to the cynical view that judges are merely 'Politicians in Judges' Robes . . . .")); see also DANIEL A. FARBER \& SuZANNA SHERry, JudgMENT CALlS: PRINCIPLE AND POLITICS IN CONSTITUTIONAL LAW 39 (2009) (rejecting "the 'if not the heavens, then the abyss' syndrome" in which judges are subject either to "complete constraint" or "boundless leeway").

61. "Trial judges tend to confront more 'easy cases,' with less ideological contestation, than appellate judges do, and trial judges' decisions have less precedential impact. As a result, their opinions are somewhat less ideological than those of appellate courts." Frank B. Cross, Decisionmaking in the U.S. Circuit Courts of Appeals, 91 CALIF. L. REv. 1457, 1481 n.162 (2003).

62. See, e.g., AT\&T Mobility L.L.C. v. Concepcion, 131 S. Ct. 1740, 1752 (2011) ("Questions of law are reviewed de novo and questions of fact for clear error."); Estate of Holl v. C.I.R., 54 F.3d 648, 650 (10th Cir. 1995) ("Questions of law are subject to a de novo standard of review.”); Bonin v. Vannaman, 929 P.2d 754, 775 (Kan. 1996) (“This court may review questions of law with an unlimited de novo standard of review."); In re Marriage of Vandenberg, 229 P.3d 1187, 1195 (Kan. Ct. App. 2010) ("to the extent the parties' arguments require statutory interpretation, this court exercises unlimited review over such questions of law."); Randall H. Warner, All Mixed Up About Mixed Questions, 7 J. APP. PRAC. \& Process 101, 113 (2005) ("Questions of law are always for judges to decide and always reviewed de novo on appeal."). 
that burdensome process is completed, United States Supreme Court justices are the final word on the United States Constitution, and state supreme court justices are the final word on their state constitutions. ${ }^{63}$ In short, all appellate judges are, as one of them puts it, "occasional legislators" ${ }^{4}$ and justices on our federal and state supreme courts are tremendously important and powerful lawmakers.

\section{The Missouri Plan's Discomfort with Legal Realism}

As just explained, all appellate judges are "occasional legislators" and justices on our federal and state supreme courts are tremendously important and powerful lawmakers. Accordingly, the democratic imperative to select lawmakers in a manner that respects the basic equality among citizens- the principle of one-person, one-vote-is especially strong with respect to the judges with the greatest lawmaking role, that is appellate judges, especially supreme court justices. Conversely, the Missouri Plan's discrimination against non-lawyers - its greater weighting of a lawyer's vote than another citizen's vote $^{65}$ - makes it an especially inappropriate way to select such judges. ${ }^{66}$

63. See, e.g., Republican Party of Minn. v. White, 536 U.S. 765, 784 (2002) (Scalia, J.) ("Not only do state-court judges possess the power to 'make' common law, but they have the immense power to shape the States' constitutions as well. Which is precisely why the election of state judges became popular." (internal citation omitted)).

64. POSNER, supra note 9, at 81.

65. See supra note 2 and accompanying text; see also infra notes 68-71 and accompanying text.

66. See Paul D. Carrington \& Adam R. Long, The Independence and Democratic Accountability of the Supreme Court of Ohio, 30 CAP. U. L. REV. 455 (2002).

[The Missouri Plan] was popular in numerous states in the twentieth century, but in its application to courts of last resort it is linked to a vision of judicial office that is technocratic and apolitical. Although there was a time in the late nineteenth and early twentieth centuries when many American lawyers and some citizens deluded themselves with the belief that judges could be trained to be professional technicians interpreting statutes and constitutions without regard to their political consequences, there is virtually no one who thinks that today.

As applied to highest state courts making decisions laden with political consequences, merit selection [the Missouri Plan] is therefore an increasingly difficult idea to sell, especially in an era in which the Supreme Court of the United States has undertaken so visibly to exercise such enormous political power and discretion with inconsistent regard for legal texts. The citizenry is quick to see that political power would be transferred from themselves to those who do the merit selecting. Despite the considerable advantages of merit selection for selecting professional technicians who sit on lower courts, its time as a politically viable alternative to judicial elections has passed.

Id. at 469-70 (internal citations omitted). See also Michael R. Dimino, Sr., Accountability Before the Fact, 22 Notre Dame J.L. EThics \& Pub. PoL'y 451, 451-52 (2008) ("Public involvement in the staffing of high courts is beneficial from a democratic perspective because of the greater discretion and policy-making authority exercised by high courts. Lower courts, by contrast, are more often bound by settled law, and the judges on such courts do not make policy to the extent that other courts do. As a result, there is less need for public involvement in the selection of 
The victims of this discrimination, however, may not be troubled by the inappropriateness of the Missouri Plan for selecting lawmakers because they may not realize that it is being used to select lawmakers. ${ }^{67}$ While most people likely would object to a lawyer's vote counting more heavily than a nonlawyer's vote in the selection of governors and legislatures, that is because most people know that governors and legislators are lawmakers. In contrast, many non-lawyers may not know that judges are lawmakers. Many nonlawyers may believe the myth that judges apply law made by others but do not, or at least should not, make law themselves. These non-lawyers may, therefore, believe that judges should be selected entirely on their professional competence and ethics and that assessments of these factors are best left to lawyers.

Thus lawyers defending the power advantage the Missouri Plan gives them over other citizens benefit from minimizing public awareness of the fact that judges inevitably make law. Regrettably, lawyers defending the Missouri Plan sometimes make their defense with published statements describing the judicial role in a way that omits the lawmaking part of that role. The following pages provide examples of such statements from the state whose version of the Missouri Plan goes farther than any other state supreme court selection process in discriminating against non-lawyers.

\section{OMISSIONS OF JUDICIAL LAWMAKING IN KANSAS}

Kansas gives the members of its bar more power than their fellow citizens in selecting the state's two appellate courts. ${ }^{68}$ As in a handful of other states ${ }^{69}$

lower-court judges, and such involvement may well be a negative influence if it encourages those judges to depart from the application of settled law."); Ware, supra note 2, at 768 ("the political/lawmaking side of judging is especially important for state supreme court justices because they are the final word on their state constitutions and common law. Accordingly, the case for democracy in judicial selection is at its strongest (and the case for elitism at its weakest) when the judges in question are supreme court justices because justices' lawmaking powers far exceed those of the "professional technicians who sit on lower courts."').

67. Of course, non-lawyers may not even realize that the Missouri Plan discriminates against them, let alone that it discriminates against them in the selection of lawmakers. The discrimination of the Missouri Plan is concealed by those who describe the nominating commission as a body of "lawyers and non-lawyers," while omitting explanation of who selects these lawyers and non-lawyers.

68. KAN. CONST. art. 3, § 5(E); KAN. STAT. ANN. §§ 20-119 to 25 (2006). For an overview of these provisions, see Stephen J. Ware, Selection to the Kansas Supreme Court, 17 KAN. J.L. \& PUB. POL'Y 386 (2008).

The Supreme Court Nominating Commission is at the center of judicial selection in

Kansas. When there is a vacancy on the Kansas Supreme Court, the Nominating Commission assesses applicants and submits its three favorites to the Governor. The Governor must pick one of the three nominees and that person is thereby appointed a justice on the Kansas Supreme Court, without any further checks on the power of the Commission. Therefore, the Commission is the gatekeeper to the Kansas Supreme Court. The bar (lawyers licensed to practice in the state) has majority control over this gatekeeper. The Commission consists of nine members, five selected by the bar and 
appellate judges in Kansas are selected in a Missouri Plan process that centers on a nominating commission some of whose members are picked in elections open only to lawyers. ${ }^{70}$ This discrimination against non-lawyers-taken farther in Kansas than in any other state ${ }^{71}$ - is often defended on the ground that appellate judging has no political/lawmaking dimension, but rather is a purely professional/technical activity. Therefore, (this faulty argument continues,) assessment of potential appellate judges ought to focus only on their professional competence and ethics, while disregarding their political views. In short, defenders of Kansas's current appellate court selection process often build their case on a foundation that crumbled about a century ago: the myth that judges do not make law.

For example, former Kansas Bar Association President, Linda Parks, describes the Kansas Supreme Court Nominating Commission, not as a body that selects lawmakers, but rather as a body "that discusses lawyers and their qualifications for a job about which lawyers know the most."72 Ms. Parks goes so far as to analogize the role of Kansas lawyers in selecting appellate judges to the role of medical doctors in referring patients to other, more specialized,

four selected by the Governor.

Id. at 386-87 nn.1-4 (emphasis added).

69. While individual state variations can make categorizing difficult, about forty states' highest courts are selected in broadly democratic ways: in contestable elections or through appointment largely controlled by democratically elected officials, typically the governor and legislature. See Ware, supra note 2, at 752-64; Brian Fitzpatrick \& Stephen Ware, How does your state select its judges?, INSIDE ALEC (American Legislative Exchange Council, D.C.), March 2011, at 9. Other than Kansas, only eight states' highest courts are selected in a process that substantially departs from democratic principles to give a member of the bar significantly greater power than one of his or her fellow citizens. See AlASKA Const. art. IV, $\S \S 5,8$ (nominating commission consists of seven members: chief justice, three lawyers appointed by governing body of the organized bar, three non-lawyers appointed by governor subject to confirmation by legislature); IND. CONST. of 1851, art. VII, $\S \S 9-10$ (1970); IND. CODE ANN. $\S \S$ 33-27-2-2, -2-1 (LexisNexis 2007) (seven members: chief justice, three lawyers elected by members of bar, three non-lawyers appointed by governor); IOWA CONST. of 1857, art. V, $\S 16$ (1962); IOWA CODE $\S \S 46.1-.2, .15$ (2006) (fifteen members: chief justice, seven lawyers elected by members of bar, seven non-lawyers appointed by governor and confirmed by senate); Mo. CONST. of 1945, art. V, § 25(a)-(d) (1976); Mo. SUP. CT. R. 10.03 (seven members: one supreme court judge chosen by members of court, three lawyers elected by members of bar, three nonlawyers appointed by governor); NEB. CONST. of 1875, art. V, § 21 (1972); NEB. REV. STAT. ANN. $§$ 24-801to 24-812 (LexisNexis 2007) (nine members: chief judge, four lawyers elected by members of bar, four non-lawyers appointed by governor); OKLA. CONST. art. VII-B, § 3 (fifteen members: six lawyers elected by members of bar, six non-lawyers appointed by governor and three non-lawyers selected by elected officials and/or other members); S.D. CODIFIED LAWS $\S$ 16-1A-2 (2007) (seven members: three lawyers appointed by president of bar, two circuit judges elected by judicial conference, and two non-lawyers appointed by governor); WYO. CONST. art. V, § 4; WYO. STAT. ANN. § 5-1-102 (2007) (seven members: chief justice, three lawyers elected by members of bar, three non-lawyers appointed by governor).

70. See sources cited supra note 69.

71. Stephen J. Ware, The Bar's Extraordinarily Powerful Role in Selecting the Kansas Supreme Court, 18 KAN. J.L. \& PUB. POL'y 392, 406-09 (2009).

72. Linda S. Parks, No Reform is Needed, 77 J. KaN. B.A. 4 (Feb. 2008). 
physicians. Parks says: "If you have a serious medical condition, you don't turn to a neighbor or a politician to find a specialist."73 Similarly, why would you want appellate judges to be selected by your neighbors (in democratic elections ${ }^{74}$ ) or by politicians (in a form of indirect, representative democracy ${ }^{75}$ )? Democracy, Parks implies, is no more appropriate in selecting appellate judges than in selecting medical specialists.

The major flaw in this analogy between appellate judges and physicians, of course, is that appellate judging is not just about professional expertise and ethics. It is also about lawmaking. As the first section of this article explained, we have known at least since the Legal Realists of the early 20th Century that judges not only apply law made by others, but also inevitably engage in lawmaking themselves. The job of an appellate judge, unlike the job of a medical doctor, involves making law. It is fine for doctors, plumbers, hairdressers, and countless other occupations to be selected entirely on the basis of technical expertise, without any role for democracy. But in a society like ours, lawmakers should be selected democratically simply because the People are sovereign. ${ }^{76}$

73. $I d$.

74. Nearly half the states use contestable elections to select their highest courts. Ware, supra note 68 , at 389 n.13. In some states, interim vacancies (that occur during a justice's uncompleted term) are filled in a different manner from initial vacancies. See AM. JUDICATURE SOC'Y, METHODS OF JUdICIAL SECTION, http://www.judicialselection.us/judicial_selection/ methods/selection_of_judges.cfm (last visited Jan. 25, 2013). Several states that use elections to fill initial vacancies use nominating commissions to fill interim vacancies. Id.

75. Senate confirmation of the executive's nominee has, for over two centuries, been the method by which federal judges are selected. U.S. CONST. art. II, § 2, cl. 2. Similarly, in a dozen states the governor nominates state supreme court justices, but the governor's nominee does not join the court unless confirmed by the state senate or similar popularly elected body. Ware, supra note 68, at 388-89 nn.11-12. Confirmation is done by the state senate in Delaware, Hawaii, Maine, Maryland, New Jersey, New York, Utah and Vermont; by the entire legislature in Connecticut and Rhode Island; and by the governor's council in Massachusetts and New Hampshire. A thirteenth state, California, can be added. Its confirmation body is a three-person commission made up of the chief justice, attorney general and most senior presiding justice of the court of appeals in California. Id.

76. When the lawmakers in question are judges, I prefer the indirect democracy of a senate confirmation appointment process to the direct democracy of contestable elections. Stephen J. Ware, The Missouri Plan in National Perspective, 74 Mo. L. ReV. 751, $772-74$ (2009). See also Richard A. Posner, Judicial Autonomy in a Political Environment, 38 ARIZ. ST. L.J. 1, 3-5 (2006) (endorsing Joseph Schumpeter as "[t]he best theorist of our actual existing democratic system").

The election of judges violates Schumpeter's conception of democratic rule. In that conception, the people vote only on the top officials, the ones who make the really consequential decisions, so that the people have some sense of whether those are the officials they want ruling them. The people are not busy monitoring the activities of the civil servants. That is not their function. They are not to waste their time trying to master issues and to figure out whether the dog catcher is catching enough dogs.

...

... [T] he election of judges even at the state or local level is contrary to the core of Schumpeter's insight, which is that we do not want our citizens to spend their time trying to master technical issues of governance. That is not an efficient division of 
The power of this point against judicial selection processes that violate a democratic society's basic equality among citizens - the principle of oneperson, one-vote - may be lost on those who do not realize that judicial selection is lawmaker selection. So members of the Kansas bar defending their power advantage (over other Kansas citizens) in judicial selection benefit from minimizing public awareness of the fact that judges inevitably make law.

Ms. Parks is not the only lawyer defending the current Kansas appellate court selection process by publishing statements describing the appellate judge's role in a way that omits the lawmaking part of this role. Such statements have also been made by Kansas judges, sitting and retired. ${ }^{77}$ For example, the late Richard Greene, then chief judge of the Kansas Court of Appeals, testified before the Kansas Legislature against a bill that would have reduced the extent to which the state discriminates against non-lawyers in judicial selection. ${ }^{78}$

In opposition to that bill, Judge Greene also published a newspaper op-ed praising the current Kansas appellate court selection process, which he described as a process designed "to ensure that only the best and brightest were selected to the Court of Appeals."

"Kansas enjoys one of the best intermediate appellate courts in the nation," Judge Greene wrote. ${ }^{80}$ The high quality of the Kansas Court of Appeals, Judge Greene said, is due to the nominating commission's focus on prospective judges' "merit," rather than their politics. In fact, Judge Greene asserted that judges" politics are "of no relevance." 81 He said Kansans need "judges whose sole allegiance is to the applicable law of our state, as well as

labor. Most of what courts do is opaque to people who are not lawyers. It is completely unrealistic to think that the average voter will ever know enough about judicial Id.

performance to be able to evaluate judicial candidates intelligently.

77. See infra notes 85-86 and accompanying text.

78. The bill, HB 2101, would have eliminated such discrimination with respect to the Kansas Court of Appeals but left it in place with respect to the Kansas Supreme Court, available at http://www.kslegislature.org/li_2012/b2011_12/measures/hb2101/.

79. Judge Richard D. Greene, Don't politicize judicial appointment system, THE WiCHITA EAGLE (Feb. 24, 2011), available at http://www.kansas.com/2011/02/24/1733731/dont-politicizejudicial-appointment.html\#ixzz1ZCLAP7wA.

80. Id.

81. Court of appeals judges appointed by the governor, confirmed by the Senate; eliminating the nominating commission for the court of appeals: Hearing on HB 2101 Before $\mathrm{H}$. Comm. on Judiciary, 2011 Leg. (Ks. 2011) (written testimony of Chief Judge Richard D. Greene, at 11) ("Judges should be chosen based on the criteria set forth in K.S.A. 20-3004 to bring intelligent, experienced, well-reasoned, and impartial justice to every case before them. Their politics-their allegiance to a Governor or to the Senate-are not only of no relevance, but should never take the front seat to merit based qualifications."). The false dichotomy between "politics" and "merit" in judicial selection is discussed infra Section IV.

http://www.kansas.com/2011/02/24/1733731/dont-politicize-judicial-

appointment.html\#ixzz1ZCLAP7wA. 
our state and federal constitutions." $" 82$

Yes, of course judges' allegiance should be to the law, including our state and federal constitutions. But that allegiance does not ineluctably guide the judge to make a particular choice among various reasonable interpretations of a vague or ambiguous constitutional or statutory provision. Reasonable people of good faith, including judges, can disagree about the best interpretation of such provisions and therefore the best result of the particular case. Claims to the contrary do not acknowledge the reality that the first section of this article showed has been "deeply rooted" for generations now-that judicial interpretation of constitutional and statutory ambiguities necessarily involves judgments of policy by the court. ${ }^{83}$

And what of the common law, which went unmentioned in Judge Greene's anti-realist argument that judges" politics are "of no relevance"? ${ }^{84}$ He said "[w]e need . . . judges who will fairly and impartially interpret and apply Kansas law without regard to political ideology." 85 But this description of the judicial role does not account for the fact that judges make the common law, not just "interpret and apply" it. In sum, it is unfortunate that the chief judge of one of Kansas's two appellate courts publicly described the role of an appellate judge in a way that omitted the lawmaking part of that role.

Other defenders of the current Kansas appellate court selection system similarly ignore about a century of legal realism to assert the irrelevance of judges' political views ${ }^{86}$ and the absence of judicial lawmaking. ${ }^{87} \mathrm{~A}$ particularly striking example of anti-realism, by Kansas District Court Judge Janice D. Russell, says that judges research to "reveal what the law is" and then simply "must follow the rule of law in deciding cases." 88 According to Judge Russell:

courts are fair and impartial only when they unflinchingly apply the

82. Greene, supra note 79.

83. See supra Section I.

84. See sources cited supra note 81

85. Greene, supra note 79.

86. Retired Kansas Supreme Court Justice Fred Six says of his colleagues on both of the Kansas appellate courts: "We served on the Court as judges, not as Republicans or Democrats." Court of appeals judges appointed by the governor, confirmed by the Senate; eliminating the nominating commission for the court of appeals: Hearing on HB 2101 Before H. Comm. on Judiciary, 2011 Leg. (Ks. Feb. 16, 2011) (written testimony of Justice Fred N. Six (ret.), at 4). See also Court of appeals judges appointed by the governor, confirmed by the Senate; eliminating the nominating commission for the court of appeals: Hearing on HB 2101before H. Comm. on Judiciary, 2005 Leg. (Ks. Feb. 21, 2005) (written testimony of Justice Fred N. Six (ret.), at 6-3) (substantially the same testimony).

87. Court of appeals judges appointed by the governor, confirmed by the Senate; eliminating the nominating commission for the court of appeals: Hearing on HB 2101 Before $\mathrm{H}$. Comm. on Judiciary, 2011 Leg. (Ks. Feb. 16, 2011) (written testimony of Eugene Balloun, Kansas Association of Defense Counsel, at 2) (we want judges to "make principled decisions based only on the law and the facts of the case").

88. Janice D. Russell, The Merits of Merit Selection, 17 KAN. J.L. \& PuB. POL'Y 437, 441 (2008). 
rule of law to their cases. Application of the rule of law requires knowledge of the law; this requires the willingness and ability to research caselaw and statutes, which reveal what the law is. These abilities are essential for every level of the legal system from the lawyers to the judges. Lawyers therefore are in a better position than any other group of people to determine which applicants possess the proper combination of professional knowledge, skill, integrity, and work ethic to carry out the duties of a judge.

Judges from municipal courts right up through the Supreme Court must follow the rule of law in deciding cases. ${ }^{89}$

In what sense "must" the Supreme Court do anything in deciding cases? As noted above, unless and until the burdensome process of constitutional amendment is completed, U.S. Supreme Court justices are the final word on the U.S. Constitution and state supreme court justices are the final word on their state constitutions. ${ }^{90}$ And, of course, this includes the power to hold unconstitutional laws enacted by the other two branches of government. These basic realities are notably absent from Judge Russell's description of the judicial role. Also absent are the more mundane realities of judges inevitably making law in their choices among various reasonable interpretations of vague or ambiguous statutory provisions and their choices among various possible common law rules. ${ }^{91}$

Examples of these mundane realities follow. These examples get beyond headline-grabbing cases and the oft-studied Supreme Court of the United States to identify and analyze the judicial lawmaking embedded in the routine work of state's court system, the sort of judicial work that weaves most of the threads in the fabric of law.

\section{EXAMPLES OF JUDICIAL LAWMAKING IN KANSAS}

\section{A. Kansas Supreme Court}

This section consists of examples of lawmaking by Kansas judges. The first subsection consists of several examples from the Kansas Supreme Court and the second subsection consists of several examples from the Kansas Court of Appeals.

\section{Workers' Compensation}

A crystal clear case of lawmaking by the Kansas Supreme Court is a workers' compensation case, Coleman v. Armour Swift-Eckrich. ${ }^{92}$ As the court's opinion by Justice Beier explained,

The pertinent facts are simple and undisputed. While waiting for the start of a meeting required by her employer, Armour Swift-Eckrich,

89. Id.

90. See supra note 63 and accompanying text.

91. See supra Section I.

92. 130 P.3d 111 (Kan. 2006). 
Coleman sat on a chair with rollers, with her feet propped up on another chair. A coworker came up behind Coleman, took hold of the back of her chair, and dumped her out of it and onto the floor. The fall injured her back. There was no ill will between Coleman and her coworker, nor had Coleman done anything to provoke or encourage him. There was no evidence that such horseplay was common at Armour Swift-Eckrich or that the company had in some way condoned the coworker's actions. ${ }^{93}$

Was Coleman entitled to workers' compensation? Not under Kansas law as it stood at the time of this 2006 case. As Justice Beier's opinion for the court candidly acknowledged, "Armour Swift-Eckrich is correct that our precedent dealing with situations similar to Coleman's is clear and, if adhered to, would deny her relief." 94

So Coleman would clearly lose this case if, as the above quote from Kansas Judge Russell argues, judges merely research to "reveal what the law is" and then simply "must follow the rule of law in deciding cases." 95 Under this unrealistically narrow description of judging, the Coleman case would end in a simple ruling for the defendant. If judges do not engage in lawmaking - as Judge Russell, Judge Greene and the other Kansas lawyers quoted in section II argue - then Coleman would clearly lose this case. As Justice Beier said, "The rule is clear, . . . An injury from horseplay does not arise out of employment and is not compensable unless the employer was aware of the activity or it had become a habit at the workplace." ${ }^{96}$ A clear rule like this-according to Judge Greene's narrow description of the judicial role quoted above-compels a court to "apply [that] rule without regard to political ideology."

But this is not, in fact, what Justice Beier and her colleagues on the Kansas Supreme Court did. Rather they did what Kansas Judges Greene and Russell say never happens. Justice Beier and her colleagues engaged in lawmaking. They changed the legal rule from one contrary to their ideologies to one consistent with their ideologies.

Justice Beier's opinion started by criticizing the old rule, while acknowledging that it was, in fact, the rule prior to her opinion by which the Supreme Court made new law. Here again is the above quote from Coleman, but now with the formerly omitted words restored and italicized: "The rule is clear, if a bit decrepit and unpopular: An injury from horseplay does not arise out of employment and is not compensable unless the employer was aware of the activity or it had become a habit at the workplace." ${ }^{98}$

Who decided that this rule is "decrepit and unpopular" and so should be changed? Was it the Kansas Legislature? No, it was the Kansas Supreme

93. Id. at 112 .

94. Id. at 114 .

95. Russell, supra note 88.

96. Coleman, 130 P.3d at 114.

97. See Greene, supra note 79.

98. Coleman, 130 P.3d at 114. 
Court. It was judges, not legislators, who decided that this legal rule was bad policy. It was judges, not legislators, who changed the law to bring it in line with what the lawmaking judges thought was good policy. As Justice Beier candidly stated:

Coleman cannot prevail on this appeal unless we are willing to do now what this court was unwilling to do . . . in 1946: Reevaluate the wisdom of the horseplay rule. Sixty years later, we think it is time to do so.

Coleman is correct that the climate has changed since [an earlier case] was decided. The Kansas rule, once in the clear majority [around the country], is now an anachronism.

Courts of last resort, such as this one, are not inexorably bound by their own precedents. They follow the rule of law established in earlier cases unless clearly convinced that the rule was originally erroneous or is no longer sound. State v. Marsh, 278 Kan. 520, Syl. đI 23, 102 P.3d 445 (2004). We are clearly convinced here that our old rule should be abandoned. Although appropriate for the time in which it arose, we are persuaded by the overwhelming weight of contrary authority in our sister states and current legal commentary. ${ }^{99}$

Contrary to Judge Russell's anti-realist statement quoted above, Justice Beier acknowledges that nothing tells "courts of last resort"100 what they "must"101 do in deciding cases. Rather than being compelled to "follow the rule of law," as Judge Russell claims, Justice Beier rightly says the Kansas Supreme Court may change the state's common law if the judges on this court believe some aspect of that law "is no longer sound." 102 Those sitting on the Kansas Supreme Court, like judges sitting on other states' high courts, make common law based on what they are "persuaded" is "appropriate for the time."103

Those are the words of a unanimous opinion of the Kansas Supreme Court and they are not earth-shattering. They are merely describing something virtually every lawyer has seen since the first year of law school. State supreme courts make common law based on what they are persuaded is appropriate for the time. Changing the law is what state supreme courts do with common law rules they believe to be "decrepit and unpopular." They overturn the decrepit and unpopular old law and make new law, which they believe will be more in keeping with contemporary society. This lawmaking by state supreme courts is not always done as openly as it was by the Kansas Supreme Court in Coleman, but it is done from time to time. It is part of the job. We have known this at least since the legal realists of the early 20th Century.

99. Id. at 115-16 (emphasis added).

100. Id. at 116.

101. Russell, supra note 88.

102. Coleman, 130 P.3d at 116.

103. Id. at 116. 


\section{Product Liability}

The Coleman opinion may be one of the clearest examples of Kansas judges making common law because of the duality of the court's choice: whether to keep or reject an existing rule. In contrast, legal rules are not always so "black or white," but often more like "shades of gray." That is, courts sometimes make law, not by changing a legal rule to its polar opposite in a single case, but rather by changing it gradually over several cases, spread over many years. ${ }^{104}$ Product liability law is an example of this incremental judicial lawmaking in Kansas, as it is in other states.

Must a product liability plaintiff prove the defendant's negligence in order to recover? No, the Kansas Supreme Court held in Brooks v. Dietz, ${ }^{105}$ which brought strict products liability into Kansas law. The Brooks court deemed "correct" the assertion that it had "never explicitly adopted the doctrine of strict liability," 106 but pointed out that it had "for years recognized something closely akin to strict liability in the food and body preparation cases."107 Continuing this history, the Brooks court said: "In recent years we have gone beyond the 'food and body preparation' cases and have held manufacturers and sellers strictly liable for other dangerously defective products." 108 Brooks then endorsed what it rightly called the "seminal" case of Greenman v. Yuba Power Products, Inc. ${ }^{109}$ This California case, according to the Kansas Supreme Court, "recognized that liability for damages resulting from putting in commerce a dangerously defective product is not the result of contract but, like other tort liability, is imposed by public policy." 110

Yes, "public policy," indeed. Public policy as determined by a California court, which, along with other factors, persuaded courts elsewhere in the country, including the Kansas Supreme Court, to change their states' laws to adopt this policy as well. In Brooks, the Kansas Supreme Court recounts the history of Kansas product liability law changing, incrementally, through a series of judicial decisions. It is a very typical story of how judges make the common law. And it is a story, told by the highest judges in Kansas, of how their court made an important part of the common law of Kansas.

Adopting strict liability was not the end of the Kansas Supreme Court's lawmaking role in product cases. I will not mention all the twists and turns but note only two. First, in a case alleging defective design of a product, can a

104. See Widiss, supra note 42 ("notwithstanding respect for precedent, common law courts reconsider prior precedents in response to changing needs or evolving norms; often, this occurs gradually as prior decisions are distinguished and new decisions slowly accumulate until ultimately a high court announces a new rule").

105. 545 P.2d 1104 (Kan. 1976) ("We have concluded the time has come for this court to adopt the rule of strict liability ....").

106. Id. at 1107.

107. $I d$.

108. $I d$.

109. 377 P.2d 897 (Cal. 1963).

110. Brooks, 545 P.2d at 1107 . 
manufacturer be liable for a danger that is "open or obvious"? Yes, according to the Kansas Supreme Court decision in Siruta v. Hesston Corp. ${ }^{111}$ This ruling was reaffirmed 17 years later in Delaney v. Deere and Co. ${ }^{112}$ which acknowledged that "the open and obvious rule barring recovery in a design defect case" was "still recognized in a few jurisdictions." 113 In other words, Siruta's rejection of the "open and obvious" rule barring recovery was a lawmaking choice by the Kansas Supreme Court. It had the option to retain that legal rule - as some other states' courts had done — but it chose to reject that rule.

The Delaney court continued the Kansas Supreme Court's role in making product liability law as Delaney held that in a design-defect case the plaintiff is not required to show evidence of a reasonable alternative design. The court chose this rule, while acknowledging that a few states chose the opposite rule. ${ }^{114}$ In choosing how to make Kansas law on this subject, the court relied in part on a law review article in which the author "states that the reasonable alternative design requirement is not supported by public policy or economic analysis." 115

In short, Delaney is yet another example of judges making law based on what they think is good policy. Delaney and these other product liability cases are examples of high court judges making law based on what they are persuaded is, as Justice Beier put it, "appropriate for the time." 116 Although these product cases may have been more gradual than Coleman, (the workers compensation case), they are similarly solid examples of the Kansas Supreme Court making law, not just applying or interpreting it. Thus they stand in refutation of descriptions (quoted in section II) of a judge's role that omit the lawmaking part of that role. follow.

A few more brief examples of lawmaking by the Kansas Supreme Court

\section{Parolees}

Does the state have a legal duty to control the conduct of parolees to prevent harm to other persons or property? When the Kansas Supreme Court confronted this question in Schmidt v. HTG, Inc., it noted a split of authority in other states. ${ }^{117}$ For example, a Washington court held that, yes, "a parole officer takes charge of the parolees he or she supervises despite the lack of a custodial or continuous relationship" and this had the effect of imposing

111. 659 P.2d 799, 806 (Kan. 1983).

112. 999 P.2d 930 (Kan. 2000).

113. Id. at 939.

114. Id. at 946 (citing John F. Vargo, The Emperor's New Clothes: The American Law Institute Adorns a "New Cloth" for Section 402A Products Liability Design Defects-A Survey of the States Reveals a Different Weave, 26 U. MEM. L. REV. 493 (1996)).

115. Id. at 946.

116. See supra note 99 and accompanying text.

117. 961 P.2d 677 (Kan. 1998). 
liability on the state. ${ }^{118}$ However, the Kansas Supreme Court "reject[ed]" this rule and said "The better-reasoned and more logical approach is that taken in [a Virginia case] which held that state parole officers did not take charge" 119 of a parolee in the relevant sense.

So Kansas law on this topic (as in the workers compensation and product liability examples above) was made, not by the legislative or executive branches, but by the judges on the Kansas Supreme Court. In Schmidt, as in the workers compensation and product liability cases above, the lawmaking judges did not pretend that they were compelled by the legislature or anyone else to choose one possible legal rule over another possible legal rule. Instead, the judges decided which view was "better-reasoned" and then made that view the law.

\section{Malpractice Actions Against Criminal-Defense Attorneys}

May a convicted criminal defendant pursue a legal malpractice action against his criminal-defense attorney without first obtaining any postconviction relief? No, he may not, the Kansas Supreme Court held in Canaan v. Bartee, ${ }^{120}$ adopting what is known as the "exoneration rule." 121 In so holding, the Kansas Supreme Court acknowledged that it was making law. The Canaan court said that "Whether a plaintiff must be exonerated in postconviction proceedings before bringing a legal malpractice action against his criminal defense attorney is an issue of first impression in Kansas." ${ }^{122}$ The court discussed earlier Kansas cases and concluded that they did not resolve the issue: "Thus, we are left to decide whether we will apply the exoneration rule in legal malpractice actions in Kansas." 123

The Canaan court reviewed decisions from courts around the country and noted that most adopted the exoneration rule but some did not. The court also summarized what it candidly called "Policy Reasons Behind the Exoneration Rule." ${ }^{24}$ The Canaan court's punch line was: "After consideration of these authorities, the varying policy justifications, and the shortcomings of the various approaches, we find the majority view persuasive. We hold that before Canaan may sue his attorneys for legal malpractice he must obtain postconviction relief." 125

Who considered "varying policy justifications" in deciding what Kansas law should be? Was it the Kansas Legislature? No, it was the judges on the Kansas Supreme Court. As in all the examples discussed above, when it

118. Id. at 686-87.

119. Id.

120. 72 P.3d 911, 914-21 (Kan. 2003).

121. See generally Amy L. Leisinger, A Criminal Defendant's Inability to Sue His Lawyer for Malpractice: The Other Side of the Exoneration Rule, (Canaan v. Bartee, 72 P.3d 911 (Kan. 2003)), 44 WASHBURN L.J. 693, at 694, 712 (2005).

122. Canaan, 72 P.3d at 914.

123. Id. at 915.

124. Id. at 916.

125. Id. at 921 . 
comes to the exoneration rule, Kansas law is what it is because high court judges chose for that to be law based on what they considered "persuasive."

\section{Negligence Per Se}

An important tort law doctrine is negligence per se. As the Kansas Court of Appeals said in Shirley v. Glass, ${ }^{126}$

the doctrine of negligence per se in Kansas differs from the negligence per se recognized in other states.

....

In Kansas, the doctrine of negligence per se . . recognizes the creation of an individual cause of action from a criminal statute or administrative regulation. An individual cause of action does not arise from every statute or regulation, but only from those which were enacted or promulgated with legislative intent to create an individual cause of action as opposed to a statute or regulation intended merely to protect the safety or welfare of the public at large. In every other state, the doctrine refers to the judicial process in negligence actions of taking a specific standard of care from a criminal statute or ordinance or from an administrative regulation that is in fact silent about issues of civil liability. ${ }^{127}$

Who were the Kansas lawmakers who made this aspect of Kansas law different from the law of other states? The judges on the two Kansas appellate courts. ${ }^{128}$ That this lawmaking is done by the Kansas Supreme Court was recognized by Kansas Court of Appeals Judge Malone who acknowledged that "in order to recover under negligence per se in Kansas, the plaintiff must establish that the legislature intended to create an individual right of action arising from the violation of a statute."129 But Judge Malone went on to criticize this law and asked the Kansas Supreme Court to change it:

There is no rational basis for requiring a party to establish that the legislature intended to create an individual right of action to recover under negligence per se. The Kansas Supreme Court should reevaluate this requirement. At the very least, the court should reevaluate the two-part test used in Kansas in determining whether a private right of action is created. ${ }^{130}$

Why did Judge Malone ask the Kansas Supreme Court, rather than the Kansas Legislature, to change this law? Because Judge Malone knows that the legislature is not the only lawmaker. Judge Malone knows that judges make law too, and that a state supreme court is an especially powerful lawmaker. In short, Judge Malone acknowledged legal realism. Unlike the Kansas judges

126. 241 P.3d 134, 150-51 (Kan. Ct. App. 2010) (describing the elements and development of negligence per se in Kansas tort law).

127. Id. (quoting William E. Westerbeke \& Stephen R. McAllister, Survey of Kansas Tort Law: Part I, 49 U. KAN. L. ReV. 1037, 1053 (2001)).

128. Such as the judges who decided Pullen v. West, 92 P.3d 584 (Kan. 2004), and Estate of Pemberton v. John's Sports Ctr., Inc., 135 P.3d 174 (Kan. Ct. App. 2006).

129. Shirley, 241 P.3d at 158 (Malone, J., concurring).

130. Id. at 161 . 
quoted in section II of this article, Judge Malone did not make the anti-realist claims that judges just "interpret and apply"131 law made by others or that judges research to "reveal what the law is" and then simply "must follow the rule of law in deciding cases." 132 Judge Malone acknowledged that the Kansas Supreme Court makes the law on negligence per se. The Kansas Supreme Court does not merely "follow" the law or "interpret" the law or "apply" the law; it "makes" the law.

In fact, Judge Malone explained that the Kansas Supreme Court had already made the law on negligence per se by choosing the legal rule Judge Malone prefers and then the Kansas Supreme Court changed the law on negligence per se by choosing the rule Judge Malone opposes. ${ }^{133}$ In a 1971 case, ${ }^{134}$ the Kansas Supreme Court did not require a negligence-per-se plaintiff to establish that the legislature intended to create an individual right of action. But then in later cases, the Kansas Supreme Court imposed this requirement. ${ }^{135}$ According to Judge Malone, the Kansas Supreme Court made the law on negligence per se. Then the Kansas Supreme Court re-made the law on negligence per se. And in the recent case of Shirley v. Glass, Judge Malone asks the Kansas Supreme Court to re-make the law on negligence per se again.

\section{Uniform Commercial Code}

All the above examples of lawmaking by the Kansas Supreme Court might be characterized as common law, rather than statutory law. But the Kansas Supreme Court makes law in its interpretation of statutes as well. An example of such a statute is the Kansas Uniform Commercial Code. Several sections of this statute were interpreted by the Kansas Supreme Court in Wachter Management Co. v. Dexter \& Chaney, Inc. ${ }^{136}$ which involved the following facts:

- A software company in the State of Washington (DCI) sought to sell software to a construction company in Kansas (Wachter).

- "After detailed negotiations, DCI issued a written proposal to Wachter . . . for . . . installation of the software, a full year of maintenance, and a training and consulting package."

- "An agent for Wachter signed DCI's proposal."

- DCI shipped the software and assisted Wachter in installing it on Wachter's computer system.

- Enclosed with the software, DCI included a software licensing agreement, also known as a "shrinkwrap" agreement, which provided (among other things) that any disputes would be resolved by courts in Washington.

131. See supra note 85 and accompanying text.

132. Russell, supra note 88.

133. Shirley, 241 P.3d at 158-59 (Malone, J., concurring).

134. Noland v. Sears, Roebuck \& Co., 483 P.2d 1029 (Kan. 1971).

135. Shirley, 241 P.3d at 158-59 (Malone, J., concurring).

136. 144 P.3d 747 (Kan. 2006). 
The Kansas Supreme Court held that the parties' contract did not require that disputes be resolved by Washington courts. In reaching this conclusion, the court interpreted the Kansas Uniform Commercial Code (UCC) as providing that a contract was formed when Wachter's agent signed DCI's proposal, ${ }^{137}$ so the later delivery of the shrinkwrap agreement made the shrinkwrap agreement an offer to modify an existing contract. That offer was never accepted by Wachter, the Kansas Supreme Court said, so the original contract (with no terms on where disputes would be resolved) continued to state the parties' rights and duties. ${ }^{138}$

In contrast, a dissenting opinion by Justice Luckert argued that the parties' contract required that disputes be resolved by Washington courts because the UCC should be interpreted as providing that Wachter's acceptance of DCI's proposal included acceptance of the license. Justice Luckert wrote:

I disagree with the majority's analysis that the license agreement was a modification of the contract. Rather, the original offer included the license or, at least, expressed the intent of the parties that a license was a part of the offer. Wachter assented to and accepted these terms by its conduct.

DCI's letter transmitting the proposal notified Wachter that "[ $\mathrm{t}] \mathrm{he}$ proposal includes modules and licenses." Wachter did not question, object to, or offer an alternative to the proposal. Instead Wachter signed the proposal, thus accepting the offer which included licenses. $^{139}$

Importantly, Justice Luckert's dissent cited and analyzed two sections of the Kansas UCC, § 2-204 and $§ 2-209,{ }^{140}$ and these two sections were also among those cited and analyzed by the majority opinion. ${ }^{141}$ In short, both majority and dissent were interpreting the same statutory language, but they came to different conclusions about the law.

This is not shocking. As the first section of this article explained, the language of statutory and constitutional provisions is sometimes vague or

137. Id. at 751 .

DCI's proposal requested Wachter to accept its offer to sell Wachter software by signing the proposal above the words "[p]lease ship the software listed above." Accordingly, Wachter accepted DCI's offer to sell the software to it by signing the proposal at Wachter's office in Lenexa. Thus, a contract was formed when Wachter accepted DCI's offer to sell it the software, indicating agreement between the parties. Id.

138. "Proposed amendments that materially alter the original agreement are not considered part of the contract unless both parties agree to the amendments. UCC 2-209 requires express assent to the proposed modifications." Id. at 752 (citations omitted). "DCI argues that Wachter expressly consented to the shrink wrap agreement when it installed and used the software rather than returning it. However, continuing with the contract after receiving a writing with additional or different terms is not sufficient to establish express consent to the additional or different terms." Id.

139. Id. at 755 (Luckert, J., dissenting).

140. Id. at 756 .

141. Id. at 755 . 
ambiguous. Such provisions do not compel a single result in each case that might arise, as reasonable people can disagree about the best interpretation of the provisions and therefore the best result of the particular case. "The legal realists saw the interpretation of statutory ambiguities as necessarily involving judgments of policy and principle. They insisted that when courts understand statutes to mean one thing rather than another, they use judgments of their own, at least in genuinely hard cases." 142

This case, Wachter, was a genuinely hard case. Confirming this, both the majority and dissent were able to cite cases from other jurisdictions interpreting the same statutory language in other states' versions of the UCC. ${ }^{143}$ Just as this statutory interpretation split the Kansas Supreme Court, it similarly split judges elsewhere in the country. In some parts of the country the law is that a shrinkwrap license is part of the original contract and thus enforceable, while in other parts of the country the law is that a shrinkwrap license is not part of the original contract so it is only enforceable if the parties modify their original contract to include the license. ${ }^{144}$ The same statutory language around the country results in different law because different judges have made different law while interpreting the same statutory language.

This is no more surprising than the aforementioned examples of judges making the common law. Judges making law in interpreting statutes is also inevitable and routine. It is simply part of what judges do.

Interestingly, three members of the Kansas Supreme Court dissented from Wachter. Justices Nuss and Beier joined Justice Luckert's dissenting opinion. So it was a 4-3 decision. Had one more member of the court been persuaded by the dissent's interpretation of the UCC then that interpretation would have become Kansas law. This shows the lawmaking power of each individual appellate judge. Just as a single state legislator's vote can mean the difference between a state's law including one rule or another, so a single judge's vote can mean the difference between a state's law including one rule or another. ${ }^{145}$

142. Sunstein, supra note 28, at 2591.

143. The majority cited Step-Saver Data Systems, Inc. v. Wyse Technology, 939 F.2d 91, 98 (3d Cir. 1991) (refusing to uphold a shrink wrap license agreement as an amendment to the parties' contract); Arizona Retail Systems v. Software Link, 831 F. Supp. 759, 764 (D. Ariz. 1993) (concluding that a software company could not unilaterally change the terms of a preexisting contract by including a shrink wrap license agreement with the software when it shipped); Klocek v. Gateway, Inc., 104 F. Supp. 2d 1332, 1341-42 (D. Kan. 2000) (denying the application of an arbitration clause contained in a form with standard terms packaged inside a computer box); United States Surgical Corp. v. Orris, Inc., 5 F. Supp. 2d 1201, 1206 (D. Kan. 1998) (rejecting "single use only" language on the packaging because there was no evidence that the parties agreed on this limitation in the contract), while the dissent cited Hill v. Gateway 2000, Inc., 105 F.3d 1147, 1149-50 (7th Cir.), cert. denied 522 U.S. 808, 118 S. Ct. 47, 139 L. Ed. 2d 13 (1997); ProCD, Inc. v. Zeidenberg, 86 F.3d at 1452-53; Brower v. Gateway 2000, 246 A.D.2d 246, 25051, 676 N.Y.S.2d 569 (1998); and Mortenson Co. v. Timberline Software, 140 Wash.2d 568, 58384, 998 P.2d 305 (2000).

144. Id.

145. See State v. Marsh, 102 P.3d 445 (Kan. 2004). 


\section{B. Kansas Court of Appeals}

The cases just discussed show that the Kansas Supreme Court, like any other state's high court, inevitably makes law. One might concede that supreme court justices make law but nevertheless contend that intermediate appellate court judges merely "interpret and apply" the law, rather than make the law. ${ }^{146}$ In fact, however, Kansas Court of Appeals judges are lawmakers, too. This was acknowledged by soon-to-be-Justice Lawton Nuss in 2002. ${ }^{147}$ As Nuss said, when the Court of Appeals was created some

believed that the new court primarily would make a "simple review of trial records" and correct the trial errors, e.g., evidentiary rulings. It would not develop and interpret the law. That function would remain with a supreme court that, now freed from its timeconsuming "correction of trial error" function, would have time for "more deliberate and mature consideration of cases having significant precedential value." 148

The reality, Nuss explained, has been quite different:

The [appeals] court has not acted solely as a corrector of routine trial error, however. For the first eight months of 2001, for example, 150 of its opinions were published. During this same time frame, the Supreme Court published 118 of its own opinions, revealing that a large percentage of the precedential cases in Kansas that year came from a court whose only reason for existence originally had been to provide more accessible, speedier and less costly appellate review for Kansas litigants. Since the Supreme Court has granted petitions for review in less than $3 \%$ of the court of appeals' opinions - which include the published ones - the higher court has apparently endorsed

In State v. Kleypas, 272 Kan. 894, 40 P.3d 139 (2001), [this court] unanimously upheld the constitutionality of K.S.A. 21-4624(e). Now, without any intervening change in substantive law, the majority opinion overrules Kleypas, not because the statute as construed is unconstitutional, but because the majority decides the Kleypas court exceeded its judicial authority in construing the statute. Kleypas was a 4 to 3 decision, consisting of a majority opinion and two written dissents. None of the three opinions took the position that the Kansas death penalty law must be struck down as constitutionally impermissible. The majority opinion upheld the law with an extremely minor judicial construction relative to equipoise, with the three dissenters upholding the law as written. In the case before us, another 4 to 3 decision, the majority concludes the death penalty is fatally flawed and rejects the majority's action in Kleypas which remedied the perceived equipoise flaw. There has been no change in relevant constitutional law as expressed by the United States Supreme Court. The only change has been the composition of the Kansas Supreme Court occasioned by the retirements of Justices Larson, Six, Lockett, and Abbott. While fidelity to the doctrine of stare decisis is not an "inexorable command," we should be highly skeptical of reversing an earlier decision where nothing has changed except the composition of the court.

Id. at 482 (McFarland, C.J., dissenting).

146. See Greene, supra note 79.

147. Lawton M. Nuss, This Learned and Versatile Court, 71 J. KAN. B. Ass'N 22, 28 (2002).

148. Id. 
this additional function of the lower court. While the court of appeals obviously is not replacing the Supreme Court, it nevertheless has clearly been allowed to assist the higher court as an important developer and interpreter of Kansas law. ${ }^{149}$

Confirming Justice Nuss's assessment of the Court of Appeals as "an important developer" of Kansas law, we now turn to examples of lawmaking by the Kansas Court of Appeals.

\section{Pleading Constructive Fraud}

"Notwithstanding the general liberality of notice pleading, a claim of fraud is one of those matters that must be pleaded "with particularity,", explained the Kansas Court of Appeals in Hemphill v. Shore. ${ }^{150}$ "Our Supreme Court, however, has not determined 'whether the heightened standard of pleading fraud with particularity applies when constructive fraud is being pled' in Kansas." ${ }^{151}$ Here, the judges on the Kansas Court of Appeals acknowledge that the judges on the Kansas Supreme Court make law. The appeals judges in Hemphill did not say that the Kansas Legislature has not made the law on the pleading standard for constructive fraud. The appeals court judges evidently do not expect the legislature to make such law. The appeals court judges do expect the Kansas Supreme Court to make such law.

However, the Kansas Supreme Court has not yet made such law, so what did the appeals court judges do? They made the law on the pleading standard for constructive fraud. They held that the heightened standard applies: "we are persuaded by the reasoning in the numerous court decisions [mostly outside Kansas] that have held that the specificity in pleading requirement applies to a constructive fraud claim." ${ }^{52}$ Did the Court of Appeals have the power to rule the other way and thus make Kansas law different? Yes, the judges on the Court of Appeals did not claim they were compelled to apply the heightened standard; they said they were "persuaded" to apply the heightened standard. They had lawmaking power and acknowledged it.

\section{Economic Loss}

In Louisburg Bldg. \& Development Co., L.L.C. v. Albright, ${ }^{153}$ plaintiffs asserted both a breach of contract claim and a fraud-in-the-inducement claim. The district court granted defendant a judgment on the fraud-in-theinducement claim because of the economic-loss doctrine. ${ }^{154}$ Was this district

149. Id.

150. 239 P.3d 885, 892 (Kan. Ct. App. 2010).

151. Id.

152. Id. at 893 .

153. 252 P.3d 597 (Kan. Ct. App. 2011).

154. Id. at 621. The Court of Appeals summarized the economic loss doctrine as follows:

The economic-loss doctrine originated in products-liability law, preventing purchasers from suing in tort where the damages claimed were purely economic - stemming from product-repair costs, product-replacement costs, inadequate product value, or lost profits resulting from product defects. To recover in tort, the product purchaser with merely disappointed economic expectations had to demonstrate some "harm above and 
court ruling correct or in error? In answering this question, the Court of Appeals cited Kansas cases ${ }^{155}$ but did not suggest that these precedents were right on point. That is, the appeals court judges did not suggest that these precedents compelled them to rule one way or the other. Instead, the appeals court judges pointed out that:

In the context of claims for fraud in the inducement, the economicloss doctrine has produced exceptional inconsistency. On one hand, a majority of states have held that the economic-loss doctrine never applies to fraud-in-the-inducement claims. . . . On the other hand, a minority of states have applied the economic-loss doctrine to fraudin-the-inducement claims that merely attempt to recover damages resulting from unfulfilled contractual promises. ${ }^{156}$

The Court of Appeals then adopted the minority approach because "The minority's approach is logical." 157 As it may well be. But a majority of states adopted the contrary approach so many courts must see logic in that approach, as well. In short, reasonable people can disagree about whether it is good policy for the economic loss doctrine to apply to any fraud-in-the-inducement claims. Who got to convert their views on this policy question into Kansas law? The judges on the Kansas Court of Appeals. In doing so, they made Kansas law on the economic loss doctrine.

\section{Settlement Agreements}

Similar lawmaking by the Kansas Court of Appeals is evident in RoofTechs Intern, Inc. v. State, ${ }^{158}$ which involved a particular sort of settlement agreement. The agreement purportedly assigned, from one settling party to another settling party, claims against a non-settling party. The Court of Appeals said, "The legality of this kind of agreement has been, heretofore,

beyond a broken contractual promise." The doctrine initially aimed to prevent contract law from dissolving into tort law by drawing a distinction between commercial transactions, where contract law protects economic expectations, and consumer transactions, where tort law remedies physical injuries to individual consumers.

The doctrine has since expanded to serve as the dividing line between contract and the broader array of tort claims, including claims for negligence and strict liability. Three policies seem to be driving the expansion of the doctrine: (1) protecting parties' expectations with respect to their bargained-for limited liability; (2) encouraging the buyer to insure against the risk of economic loss; and (3) preventing "unnecessary complexity" resulting from the assertion of tort claims that merely duplicate breach-ofcontract claims. This court has recognized similar policies in its own applications of the economic-loss doctrine. This court has also held that these policies remain applicable when the purchaser is an individual consumer, as opposed to a sophisticated commercial purchaser. Id. at 621-22 (citations omitted).

155. See, e.g., id. at 623 ("The Kansas Supreme Court has previously recognized the importance of this policy, warning against the 'danger' of allowing claims that attempt to turn every breach of contract into a tort. See Gerhardt v. Harris, 261 Kan. 1007, 1021, 934 P.2d 976 (1997)").

156. Id. at 622 .

157. $I d$. at 623 .

158. 57 P.3d 538 (Kan. Ct. App. 2002). 
undetermined in Kansas." 159 The Court of Appeals then made law by enforcing the agreement before it. ${ }^{160}$

In Roof-Techs, the Court of Appeals did not suggest that its hands were tied by a statute or by prior rulings of the Kansas Supreme Court. To its credit, the Court of Appeals' opinion frankly recognized that it was in uncharted territory. So the appellate judges did what appellate judges do when in uncharted territory, they stepped up to their role as "occasional lawmakers"161 and made the law on these sorts of settlement agreements.

\section{Medical Devices}

All the above examples of lawmaking by the Kansas Court of Appeals might be characterized as common law, rather than statutory law. But the Kansas Court of Appeals makes law in its interpretation of statutes as well. An example is $\S 360 \mathrm{k}(\mathrm{a})$ of the Medical Device Amendments to the Food, Drug, and Cosmetic Act. ${ }^{162}$

Does this statute preempt state common-law tort claims alleging liability as to Class III medical devices? Ultimately, this question could be resolved by the U.S. Supreme Court. Until then, different jurisdictions may have different laws because different courts may rule differently. In Troutman v. Curtis, ${ }^{163}$ the Kansas Court of Appeals made Kansas law by holding that state commonlaw tort claims alleging liability as to a Class III medical device are preempted by $\S 360 \mathrm{k}(\mathrm{a}) .{ }^{164}$

\section{Legal Duty to Support a Negligence Claim}

A final example of lawmaking by the Kansas Court of Appeals, Berry v. National Medical Services, Inc., ${ }^{165}$ is a mixture of judges making common law and judges making law by interpreting statutes. Berry, a nurse licensed by the Kansas State Board of Nursing, admitted to the Board that she had a problem with alcohol dependency and agreed to submit to random testing to confirm that she was abstaining from alcohol. ${ }^{166}$ The Board contracted with defendant Compass Vision, Inc., to administrator this program, and Compass engaged defendant, NMS, to provide alcohol testing for nurses and to report its test results to the Board. ${ }^{167}$ Berry's test results were positive, and the Board revoked Berry's nursing license. ${ }^{168}$ Berry brought negligence actions against Compass and NMS. ${ }^{169}$ Defendants denied they owed a legal duty to Berry and

159. Id. at 550 .

160. Id. at 554 .

161. See POSNER, supra note 9 , at 81 .

162. 21 U.S.C. $\$ 301$ (2000 \& Supp. III 2003).

163. 143 P.3d 74 (Kan. Ct. App. 2006).

164. Except for a claim that the manufacturer failed to comply with the approved federal standards.

165. 205 P.3d 745 (Kan. Ct. App. 2009).

166. Id. at 748 .

167. Id.

168. Id. at 748-49.

169. Id. at 749 . 
persuaded the district court to dismiss Berry's negligence claim. ${ }^{170}$

The Kansas Court of Appeals majority reversed, holding that defendants did owe a legal duty to Berry. ${ }^{171}$ In so holding, the judges made law. The Court of Appeals majority acknowledged this in noting that "[w]hether a legal duty exists is an issue of law over which appellate courts have unlimited review." 172

While the majority resolved this issue of law in Berry's favor, Judge Buser's dissenting opinion would have resolved it in favor of the defendants. ${ }^{173}$ In short, different judges on the Court of Appeals favored different legal rules. The majority of the three judges deciding the case got to make the law simply because they outnumbered the dissenting judge. Just as a single state legislator's vote can mean the difference between Kansas law including one rule or another, so a single Court of Appeals judge's vote can mean the difference between Kansas law including one rule or another.

While negligence law, including the duty element of a negligence claim, is generally common law, Kansas case law on whether to impose a duty considers, among other factors, whether there is a "public policy against imposing the claimed duty on the defendant." opinion concluded that there was and reached that conclusion by interpreting certain Kansas statutes. ${ }^{175}$ By contrast, the majority interpreted the statutes differently and thus concluded that those statutes did not indicate a public policy against imposing the duty. ${ }^{176}$ The point, of course, is not to assess

170. $I d$.

171. Id. at 750 .

172. Id. at 749 .

173. Judge Buser "Would hold that laboratory testing facilities and third-party administrators do not owe a duty to nurses addicted to alcohol whose specimens they test under a contract with the administrative agency empowered by the legislature to regulate the professional competency of nurses." Id. at 753.

174. Id. at 749 .

175. "It is the public policy of this state, as decided by the Kansas Legislature in its enactment of K.S.A. 65-1120, that the Kansas State Board of Nursing (Board) has authority to establish, regulate, and enforce the professional competency of nurses. Moreover, pursuant to K.S.A. 77-621(c), the legislature has granted the judiciary a limited power to review (using a deferential standard) the Board's disciplinary actions against impaired nurses. These legislatively established public policies are undermined by the majority's decision of first impression in Kansas." Id. at 752-53.

176.

Finally, there is no public policy against imposing liability. We defer to our legislature in establishing public policy and find no expression by our legislature that urinalysis providers are exempt from liability for their negligence in providing faulty results or interpretations. These defendants, as testing providers to the Board, do not argue that they are protected by sovereign immunity. We find no public policy that would immunize these defendants from the consequences of their actions. Therefore, the third element for establishing a duty has been satisfied.

In this regard we note the dissent's public policy argument which is predicated upon the fact that this claim arose in the context of administrative proceedings to determine Berry's fitness to practice her profession. The dissent seems to confuse the wrongful 
whether the majority or dissent better interpreted the statutes. The point is to note another example in which judges make law in the course of interpreting statutes.

\section{CONCLUSION}

What do these examples from Kansas's two appellate courts show? Only judges making law. No surprise, of course. We have known, at least since the Legal Realists of the early 20th Century, that judges make law. And it is similarly well established that, although judging has a professional/technical side, as well as a political/lawmaking side, the latter's importance rises, the higher the court. All appellate judges are "occasional legislators"177 and supreme court justices are tremendously important and powerful lawmakers. So no one within the mainstream of our country's 20th and 21st Century legal thought will be surprised by this article's demonstration of repeated lawmaking by the judges on the Kansas Supreme Court and the Kansas Court of Appeals. ${ }^{178}$

The decisions summarized in this article show Kansas's two appellate courts making law in the course of deciding cases. Whether the law made in any of these cases is good or bad policy is, of course, beside the point. The point is that the policy views of appellate judges matter because appellate judges are lawmakers - so the Kansas judges and lawyers who omit lawmaking from their description of the appellate judge's role omit something

conduct Berry complains of with the product of that wrongful conduct. The wrongful conduct in this action is the claimed negligence of Compass and NMS, not the action of the Board in revoking Berry's nursing license. The consequence of this claimed negligence was the loss of Berry's license and the damages that followed.

We conclude that under Kansas law Berry has alleged the breach of a recognizable duty, and she has pled a cause of action for which relief may be granted. Id. at 750 .

177. POSNER, supra note 9 , at 81.

178. As then-State Senator, now-Attorney General of Kansas, Derek Schmidt, said: [T] he law is not always black-and-white — particularly when it presents itself in the form of the difficult issues that confront the Supreme Court [of Kansas]. If the difficult questions of law could always - or even usually - be settled with a clearly correct answer merely by reading and applying the constitutions, statutes and cases, then there would be no need to have seven justices on the Supreme Court. One would suffice - so long as that one was sufficiently learned in the law.

But, of course, that is not the nature of the law - as evidenced, inter alia, by the many split decisions of our Supreme Court. Being properly experienced and credentialed in the law is a necessary but not sufficient condition for being an excellent justice. Judgment also is required as is a sensitivity to societal norms, trends, conditions and expectations. To put the point another way, justices require a certain amount of political savvy.

Judicial philosophy matters. Of course it does. To pretend otherwise is to believe the law is a math or science rather than an art or social studies.

Constitutional Amendment to have the Supreme Court Justices appointments Subject to Consent by the Senate: Hearing on SCR 1606 before S. Comm. on Judiciary, 2005 Leg. (Ks. Feb. 21, 2005) (written testimony of Senator Derek Schmidt, at 6). 
significant. A published statement describing the appellate judge's role as though it does not include lawmaking encourages non-lawyers to believe the myth that judges apply law made by others but do not inevitably make law themselves.

Those non-lawyers who (wrongly) believe that judges are not lawmakers cannot be troubled by the fact that the Missouri Plan-even Kansas's uniquely extreme version of it $^{179}$-is an aberrant violation of our society's practice of selecting lawmakers democratically. Non-lawyers who believe in the principle that lawmakers should be selected democratically need to know that judicial selection is lawmaker selection to be troubled by the Missouri Plan's violation of this principle. Non-lawyers who do not know that judges inevitably make law may believe that the role of a judge consists only of its professional/technical side and, therefore, believe that judges should be selected entirely on their professional competence and ethics and that assessments of these factors are best left to lawyers. In short, a lawyer who omits lawmaking from a published statement about the judicial role is furthering a misimpression that helps empower lawyers at the expense of nonlawyers, in violation of basic democratic equality, the principle of one-person, one-vote.

Lawyers (in Kansas or elsewhere) who seek to defend the power advantage the Missouri Plan gives them over other citizens can honestly acknowledge that this is a power advantage in the selection of lawmakers and then explain why they believe a departure from the principle of one-person, one-vote is justified in the selection of these particular lawmakers. But no honest Kansas lawyer who has been exposed to the cases discussed in this article can defend the state's current method of appellate court selection with a description of the judicial role that omits lawmaking. Honesty requires those who believe the Kansas bar should select any member of a judicial nominating commission to acknowledge that they are advocating discrimination against non-lawyers in the selection of lawmakers. The same point undoubtedly applies as well in the other 49 states. Debate over judicial selection in the United States can be honest if it forthrightly acknowledges that judicial selection is lawmaker selection.

179. See id. at Section II (describing the Kansas process). 